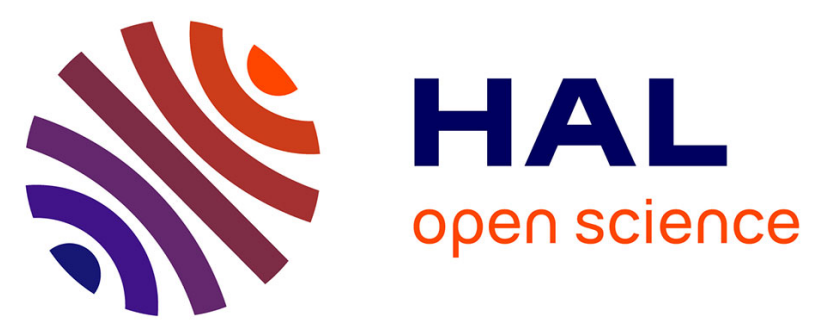

\title{
A case study of in situ analyses (major and trace elements, U-Pb geochronology and Hf-O isotopes) of a zircon megacryst: Implication for the evolution of the Egéré terrane (Central Hoggar, Tuareg Shield, Algeria)
}

O. Bruguier, R. Caby, Delphine Bosch, K. Ouzegane, E. Deloule, Bruno

Dhuime, A. Bendaoud, J.R. Kienast

\section{To cite this version:}

O. Bruguier, R. Caby, Delphine Bosch, K. Ouzegane, E. Deloule, et al.. A case study of in situ analyses (major and trace elements, U-Pb geochronology and Hf-O isotopes) of a zircon megacryst: Implication for the evolution of the Egéré terrane (Central Hoggar, Tuareg Shield, Algeria). Precambrian Research, 2020, 351, pp.105966. 10.1016/j.precamres.2020.105966 . hal-02999375

\section{HAL Id: hal-02999375 \\ https://hal.science/hal-02999375}

Submitted on 10 Nov 2020

HAL is a multi-disciplinary open access archive for the deposit and dissemination of scientific research documents, whether they are published or not. The documents may come from teaching and research institutions in France or abroad, or from public or private research centers.
L'archive ouverte pluridisciplinaire HAL, est destinée au dépôt et à la diffusion de documents scientifiques de niveau recherche, publiés ou non, émanant des établissements d'enseignement et de recherche français ou étrangers, des laboratoires publics ou privés. 


\title{
A case study of in situ analyses (major and trace elements, U-Pb geochronology and Hf-O isotopes) of a zircon megacryst: Implication for the evolution of the Egéré terrane (Central Hoggar, Tuareg Shield, Algeria)
}

\author{
O. Bruguier $^{\mathrm{a}, *}$, R. Caby ${ }^{\mathrm{a}}$, D. Bosch ${ }^{\mathrm{a}}$, K. Ouzegane ${ }^{\mathrm{b}}$, E. Deloule ${ }^{\mathrm{c}}$, B. Dhuime ${ }^{\mathrm{a}, \mathrm{d}}$, A. Bendaoud ${ }^{\mathrm{b}}$, J.R. Kienast ${ }^{\mathrm{e}}$ \\ a Géosciences Montpellier, Université de Montpellier, CNRS, Université des Antilles, Montpellier, France \\ ${ }^{\mathrm{b}}$ LGGIP, FSTGAT, Université des Sciences et de la Technologie Houari Boumedienne, BP 32 El Alia, Dar el Beida, 16111 Algiers, Algeria \\ c CRPG, UMR 5873, Université de Lorraine, CNRS, Vandoeuvre les Nancy, France \\ ${ }^{\mathrm{d}}$ Bristol Isotope Group, School of Earth Sciences, University of Bristol, Wills Memorial Building, Queens Road, Bristol BS8 1RJ, UK \\ ${ }^{\mathrm{e}}$ IPGP, 1 rue Jussieu, 75238 Paris cedex 5, France
}

\section{A R T I C L E I N F O}

\section{Keywords}

Hoggar

Neoproterozoic

Tuareg Shield

High pressure metamorphism

Zircon U-Pb dating

O-Hf isotopes

\begin{abstract}
A B S T R A C T
The Tighsi area of the Egéré/Aleksod Terrane (Tuareg Shield) contains mafic eclogites interlayered within anatectic metapelites corresponding to metabasalts coeval with a shallow water marine sedimentation. In this study we present in-situ geochronological (U-Pb) and geochemical (major and trace elements, Hf and O isotopes) analyses from a $2.6 \mathrm{~mm}$ zircon megacryst found in a high-pressure kyanite pegmatite enclosed in the metapelites.Oscillatory zoning, HREE-enriched patterns, positive Ce anomalies and the absence of negative Eu anomalies are consistent with crystallization of the megacryst from the anatectic melt. Ti-in-zircon temperatures indicate crystallization at $811 \pm 15{ }^{\circ} \mathrm{C}$ in an allanite/monazite buffered anatectic melt as evidenced by the low $\mathrm{Th} / \mathrm{U}$ ratios. Oxygen isotopes yield large intra-grain variations (7.1-12.3\%) with a gradual lowering towards the edge of the grain in contact with secondary feldspathic veinlets. These results indicate fluid-assisted oxygen isotope disturbances, consistent with the low retentivity of $\mathrm{O}$ in zircon under wet conditions. Hf isotopes do not display intra-grain variations (mean $\varepsilon \mathrm{Hf}_{\mathrm{i}}=-20.7 \pm 1.0$ ) and support production of the leucosome by melting of crustal material. U-Pb analyses of the center of the crystal provide an age of $654 \pm 5 \mathrm{Ma}(2 \sigma)$, attributed to post-peak decompression and heating. HP eclogite facies conditions in the Egéré terrane are thus significantly older than HP metamorphism in the western part of the shield (610-625 Ma) in agreement with multiple subduction events along the margins of the Tuareg Shield.The rim of the megacryst, close to feldspathic veinlets, is characterized by a significant decrease of trace elements (U, Y, HFSE), but preserved identical Hf isotope ratios, which is consistent with recrystallization processes. The rim displays a Ti-in-zircon temperature of $717 \pm 28^{\circ} \mathrm{C}$ and a U-Pb age of $584 \pm 6 \mathrm{Ma}(2 \sigma)$ coeval with the climax of batholith intrusion in Central Hoggar. Reheating and softening of the lower/middle crust at that time may have assisted and favored upward viscous flow of basement domes and escape tectonics along lithospheric shear zones. We propose that the final push of the Saharan metacraton in the east was responsible for the observed architecture of the Egéré terrane, where anatectic elongated domes of basement gneisses alternate with HP metasedimentary synforms.
\end{abstract}

\section{Introduction}

«Old zircons never die». This statement primarily comes from the large number of pioneering studies that highlighted the robustness of the U-Pb system in zircon (Lancelot et al., 1976; Black et al., 1986). The recognition that zircon is still the oldest known terrestrial material, more than thirty years after the discovery of the first very old $(>4.0 \mathrm{Ga}$ ) detrital grains (Froude et al., 1983; Compston and Pidgeon, 1986), nurtured the development of a large range of applications that aimed at using zircon, not only as a geochronometer, but also as a petrogenetic indicator in order to constrain its crystallization environment (Barth and Wooden, 2010). In turn, this fostered the development of low sample consumption, high spatial resolution in-situ techniques, which makes it possible to get information using volumes that are smaller and smaller, even reaching submicron scale (Breeding et al., 2004; Cottle et al., 2009). In addition, in-situ analyses, performed on thin- or thick-sections, provide the unique opportunity to take advantage of the textural context of

\footnotetext{
* Corresponding author.

E-mail address: bruguier@gm.univ (O. Bruguier)
} 
the studied zircon grains, which is often paramount for the interpretation of the isotopic and chemical data (e.g., Zong et al., 2010). By combining all these approaches, it is now possible to perform, on the same grain, a large range of isotopic and trace element analyses that allow accessing the wealth of information tightly retained in this unique geological recorder. In this study, we focused on a single zircon megacryst (c. $2.6 \mathrm{~mm}$ long and $1.3 \mathrm{~mm}$ large) discovered in a thin section cut in a pegmatitic leucosome from migmatitic metapelites from the Tighsi area in the Egéré terrane of the Tuareg Shield (Algeria). The large size of the megacryst enables performing major and trace element (REE, Ti) as well as isotope ( $\mathrm{U}-\mathrm{Pb}, \mathrm{Hf}$ and $\mathrm{O}$ ) analyses, thus providing a full range of information on its age, crystallization environment and, more importantly, on the behavior of these isotopic and chemical tracers. This information is then used as clues in the comprehension of processes that occurred in the Egéré terrane and that shaped the assembly of the central part of the Tuareg Shield, a patchwork of more than twenty different terranes that aggregated during the Neoproterozoic.

\section{Geological setting}

Since the work of Black et al. (1994), the Tuareg Shield (Fig. 1) has been subdivided in 23 terranes separated by lithospheric-scale shear zones. These terranes display different origins and geodynamic evolutions and include Archean/Paleoproterozoic (meta)cratons, Pan-African terranes reworking older basement, and juvenile Neoproterozoic terranes. All of these were amalgamated together during the Neoproterozoic (e.g. Caby, 2003) due to the convergence between the West African Craton on the West and the Saharan Metacraton on the East. Some of these terranes such as the Laouni, Azrou n'Fad, Tefedest, Egéré/Aleksod terranes of Central Hoggar were subsequently recognized to bear strong affinities and were con- sequently grouped together to form the LATEA superterrane (Liégeois et al., 2003), which was recently revised to include the Aouilene terrane, located West of Laouni (Liégeois, 2019). Geochronological data obtained on LATEA basement gneisses provided Paleoproterozoic ages (e.g. Bertrand et al., 1986; Barbey et al., 1989; Bendaoud et al., 2008) and, in the North of the Egéré/Aleksod terrane, 2.7-3.2 Ga Archean ages (Peucat et al., 2003). During the Pan-African cycle, LATEA is regarded as a continental passive margin, which was involved in a subduction setting as demonstrated by the recognition of several eclogitic occurrences in the Laouni (Liégeois et al., 2003), Azrou n'Fad (Zetoutou et al., 2004) and Egéré/Aleksod (Sautter, 1986; Doukkari et al., 2014, 2015; Arab et al., 2015) terranes. Collectively, these eclogitic occurrences have been interpreted as a single unit (e.g. Liégeois et al., 2003). The polarity of the subduction is still a matter of debate, but a westward subduction of LATEA is now widely accepted (e.g. Caby, 2003; Liégeois et al., 2003; Doukkari et al., 2015), which is consistent with the occurrence of the juvenile Neoproterozoic (Cryogenian to Tonian) island-arc of the Iskel terrane (Caby et al., 1982; Caby and Andreopoulos-Renaud, 1983; Bechiri-Benmerzoug et al., 2011), west of LATEA. The age of the high-pressure eclogite facies metamorphism is not known precisely, but should be older than Upper Cryogenian owing to the $685 \pm 19 \mathrm{Ma} \mathrm{Sm} / \mathrm{Nd}$ isochron age of the retrograde amphibolite facies metamorphism (Liégeois et al., 2003) in the southern part of the Laouni terrane.

In the northern part of LATEA, recent field observations along with a review of published metamorphic constraints (Caby and Bruguier, 2018) indicate that the western part of the Egéré/Aleksod terrane represents a rifted domain with possible Ocean-Continent transition relics. The geology of this area, which is the subject of this study, is composed of gneissic basement rocks (Arechchoum

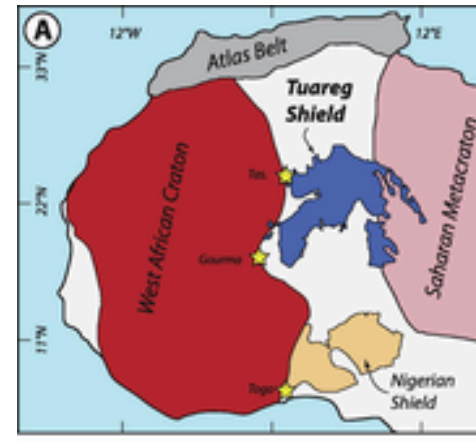

Figure 1: A. Sketch map of West Africa with the main continental landmasses (after Liegeois, 2019). Yellow stars indicate location of eclogites occurrences outcropping along the eastern margin of the West African Craton (Tas. = Tassendjanet terrane). B. Schematic map of the Tuareg Shield (after Caby 2003) with location of the Tighs: area in the Egeré terrane. Red circles are eclogites. Al. = Aleksod; $A_{2}$ = = Azrou mflad; La. = Laouni; Tas. = Tassendjanet; $\mathrm{Te} .=$ Tefedest. IGU $=$ Iforas Granulitic Unit; IOGU = In Ouzzal Granulitic Unit.

Figure 1

(Bruguier et al.)

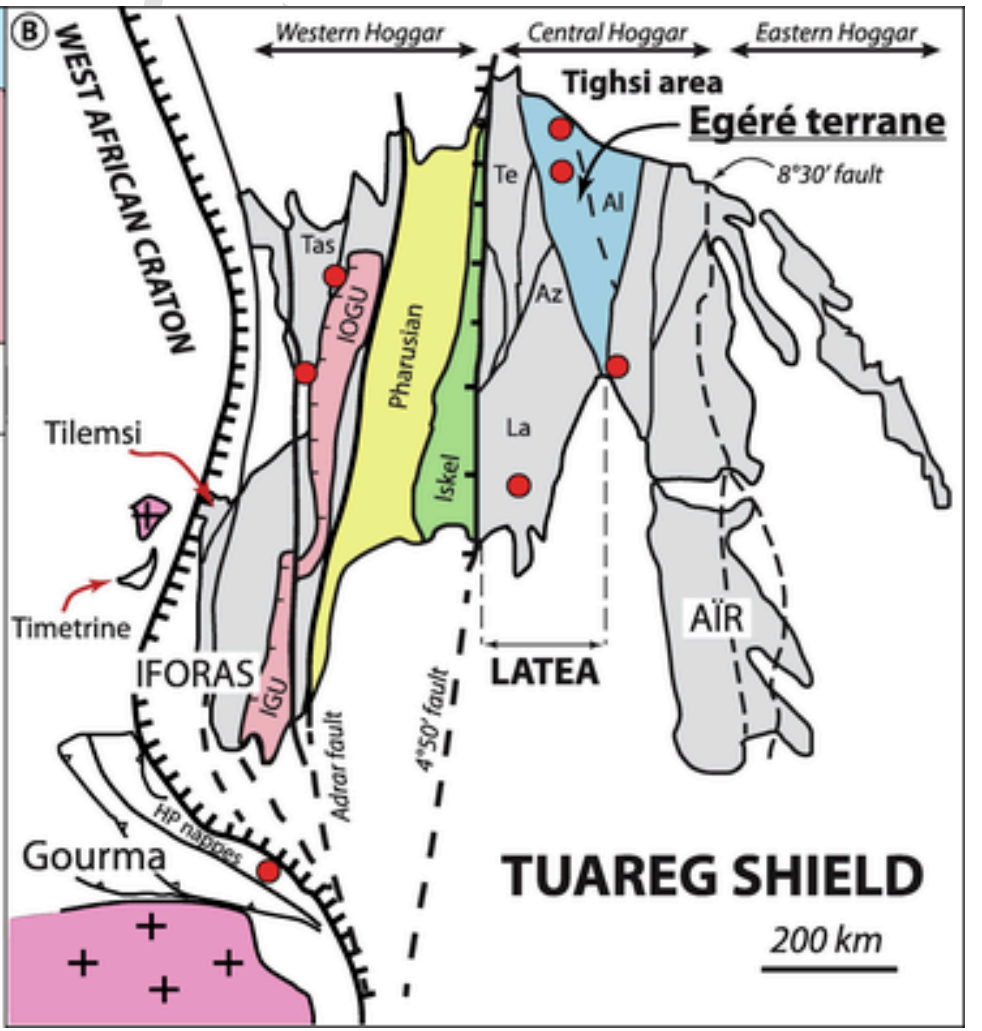

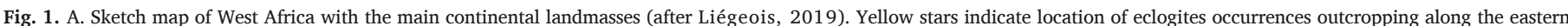

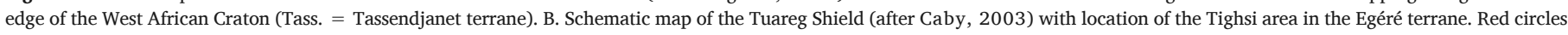

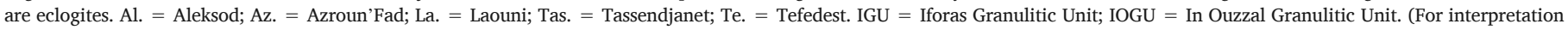
of the references to colour in this figure legend, the reader is referred to the web version of this article.) 
and Aleksod gneisses, Bertrand, 1974) and metasediments of the Egéré Group (including mafic eclogites and garnet amphibolites). The mafic eclogites and garnet amphibolites outcrop as lenses interlayered within marbles, quartzites, and metapelites and were interpreted as metabasalts and tuffs coeval with carbonate sedimentation in a shallow water marine environment (Caby and Bruguier, 2018). In the present state of our knowledge, eclogites have not been sighted in the Arechchoum gneisses, which are thus regarded as the non-eclogitised basement overthrust by the Egéré Group. Metapelites and mafic eclogites from the Egéré Group define a P-T loop from $20 \mathrm{kbar}-700{ }^{\circ} \mathrm{C}$ (eclogite facies) to $9 \mathrm{kbar}-$ $700{ }^{\circ} \mathrm{C}$ (retrograde amphibolite facies) through $16 \mathrm{kbar}-770{ }^{\circ} \mathrm{C}$ (decompression heating) (Doukkari et al., 2014, 2015; Arab et al., 2015). The sample analyzed in the course of this study was collected in the Tighsi area, which is located in the North of the Egéré terrane (see Fig. 1).

\section{Sample description}

The studied sample (T95) is a kyanite pegmatite enclosed within high-pressure kyanite- and garnet-bearing migmatitic metapelites. The rock displays a coarse-grained texture dominated by abundant white mica flakes up to $1 \mathrm{~cm}$ in size (see Fig. 2A). The sample is composed of quartz showing a secondary syn-kinematic mosaic recrystallization of low-temperature type. Large white mica porphyro- clasts display epitaxic exsolutions of thin secondary brown biotite. Clasts of primary biotite are associated and intermingled with the white mica. Untwined perthitic K-feldspar contains inclusions of minute prismatic rutile. Complex symplectitic pseudomorphs (c. 20\% vol.) are made up of secondary plagioclase, minute kyanite, white mica, biotite and fibrolite. Graphite lamellae are abundant. Besides the recrystallization of quartz, low-temperature retrogression consists in minute white micas that replace the alumino-silicates from the matrix towards their rims. The sample formed under high-pressure metamorphic conditions. Its early high-pressure mineral assemblage is represented by quartz, white mica, K-feldspar, biotite and kyanite. The decompression stage is marked by the replacement of kyanite by fibrolite and by the partial replacement of white mica by biotite. A large euhedral zircon megacryst (c. $2.6 \mathrm{~mm}$ long and $1.3 \mathrm{~mm}$ width) was discovered in the thin-section. This megacryst indents a large K-feldspar crystal on one side and is in contact with primary white mica on the other side (see Fig. 2).

\section{Analytical techniques}

\subsection{Mineral chemistry}

Major elements (including $\mathrm{Zr}, \mathrm{Hf}, \mathrm{Y}$ and $\mathrm{U}$ for zircon) were analyzed by EPMA at the University of Montpellier using a Cameca SX100 electron microprobe equipped with five wavelength-disper-

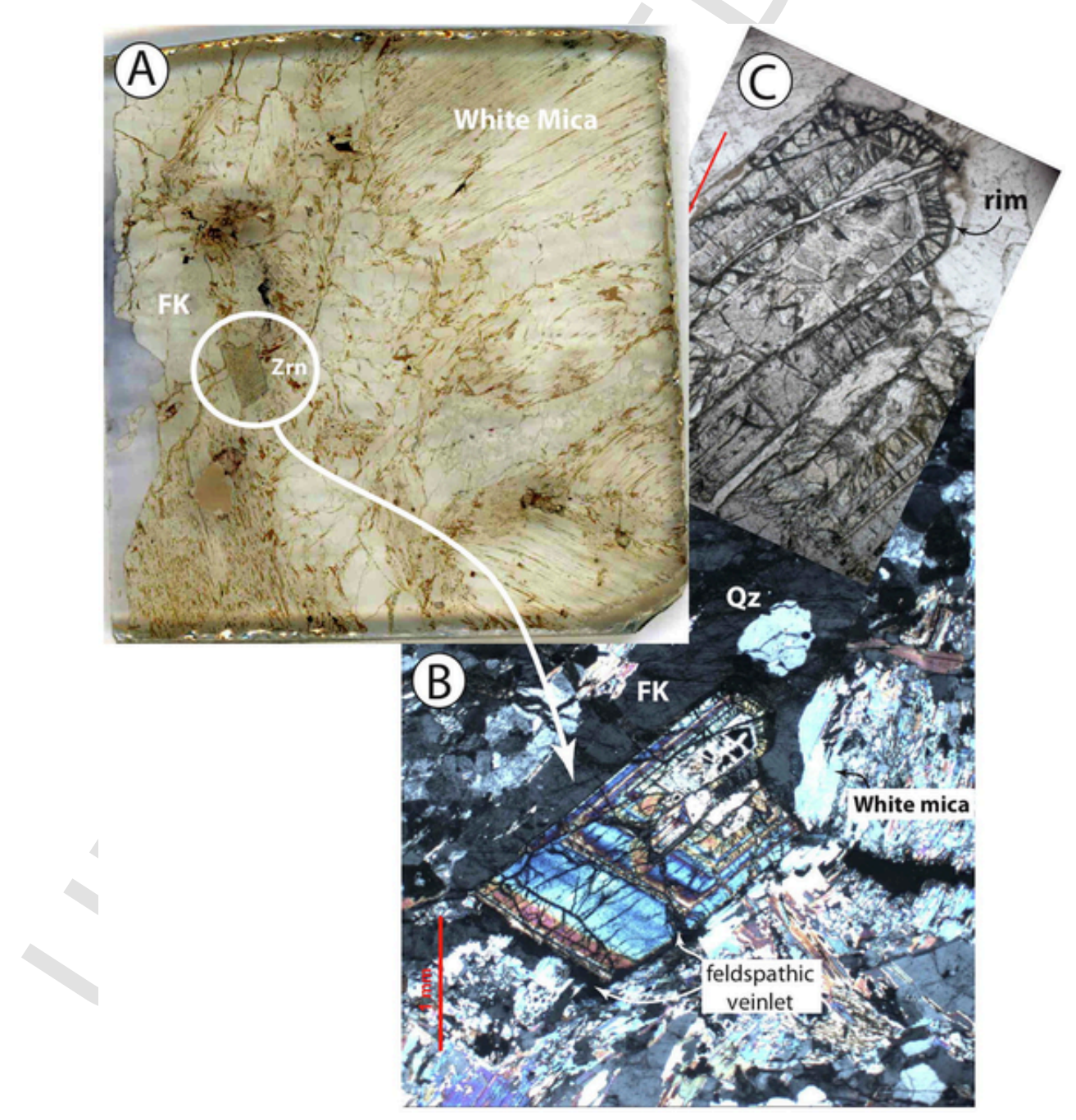

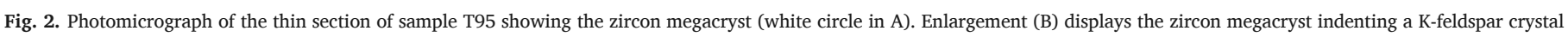

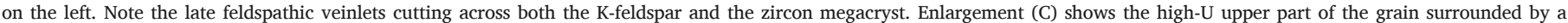
fractured rim. 
sive X-ray spectrometers (WDS). Analyses were performed using an acceleration voltage of $20 \mathrm{kV}$, a 10nA beam current and 30 s counting time for all elements. Accuracy of the results was checked by regularly analyzing the natural zircon 91,500 during analyses of the zircon megacryst (see Table 1).

Trace elements of zircon and rutile were analyzed by laser ablation inductively coupled plasma mass spectrometry (LA-ICP-MS) at Géosciences Montpellier (University of Montpellier, AETE-ISO regional facility of the OSU OREME). The analytical platform includes a eighteen years old pulsed $193 \mathrm{~nm}$ ArF excimer laser (Compex 102 from LambdaPhysik) with $200 \mathrm{~mJ}$ output energy coupled to a Thermofinnigan Element XR mass spectrometer modified by addition of a $80 \mathrm{~m}^{3} / \mathrm{h}$ Edwards primary pump in the interface to enhance sensitivity. The instrument was tuned for maximum sensitivity and low oxide production (ThO/Th at $<1 \%$ ). Ablation experiments were conducted in an ablation cell of c. $30 \mathrm{~cm}^{3}$ in a He atmosphere, which enhances sensitivity and reduces inter-element fractionation (Günther and Heinrich, 1999). The helium gas stream and particles from the sample were then mixed with $\mathrm{Ar}$ before entering the plasma. The laser was operated at a repetition rate of $3 \mathrm{~Hz}$, using a $26 \mu \mathrm{m}$ spot size and a $12 \mathrm{~J} / \mathrm{cm}^{2}$ energy density. Total analysis time was $120 \mathrm{~s}$ with the first $80 \mathrm{~s}$ used for background measurement before sample ablation. Synthetic glass NIST 612 was used for external calibration (values after Pearce et al., 1997). Internal standard normalization was done using $\mathrm{SiO}_{2}$ for zircon (31.06 wt $\%$, mean value measured by EPMA, see Table 1) and $\mathrm{TiO}_{2}$ for rutile ( $99 \mathrm{wt} \%$, stoichiometric value). Accuracy of the analyses was monitored using the fused glass standard BIR1-G glass (values taken from GEOREM preferred values) and 91,500 zircon and it was always better than 15\% (see Table 2). Data reduction was done using the software package Glitter (van Achterberg et al., 2001).

\section{2. $U-P b$ geochronology}

$\mathrm{U}$, Th and $\mathrm{Pb}$ isotopic analyses were performed using the LA-ICP-MS equipment described above (Thermofinnigan Element XR mass spectrometer coupled to a Lambda Physik Compex 102 excimer laser). The operating conditions and data acquisition were as described in earlier reports (e.g., Bosch et al., 2011), using a spot size of $26 \mu \mathrm{m}$, a repetition rate of $3 \mathrm{~Hz}$ and an energy density of $12 \mathrm{~J} / \mathrm{cm}^{2} . \mathrm{Pb} / \mathrm{U}$ and $\mathrm{Pb} /$ $\mathrm{Pb}$ ratios were calibrated against the reference material 91,500 for zircon (Wiedenbeck et al., 1995). Data evaluation was performed using the software Glitter (van Achterberg et al., 2001). Ages were calculated using the Isoplot/Ex program (Ludwig, 2003) and are quoted in the text at the $2 \sigma$ confidence level. In the course of this study, zircon material GJ1 was analyzed twice each five unknowns and provided a ${ }^{206} \mathrm{~Pb} /{ }^{238} \mathrm{U}$ age of $607.1 \pm 4.7 \mathrm{Ma}(\mathrm{n}=8)$, in good agreement with the reference value quoted in Jackson et al. (2004).

\subsection{Hf isotopes}

Lu-Hf isotopes were measured at the University of Bristol (Bristol Isotope Group) using a ThermoFinnigan Neptune ${ }^{+}$multicollector inductively-coupled plasma mass spectrometer (MC-ICP-MS) coupled with a Photon-Machine Analyte G2 Excimer laser (193 nm wavelength). Ablation was performed using a $50 \mu \mathrm{m}$ spot size. Laser frequency was $5 \mathrm{~Hz}$ and the energy density of the laser beam was $c .6 \mathrm{~J} / \mathrm{cm}^{2}$. A typical analysis was $90 \mathrm{~s}$, including a $30 \mathrm{~s}$ background measurement and a $60 \mathrm{~s}$ ablation period. Correction for the interferences and mass bias followed the Bristol routine procedure (Hawkesworth and Kemp, 2006; Kemp et al., 2009). The correction for the isobaric interference of $\mathrm{Yb}$ and $\mathrm{Lu}$ on ${ }^{176} \mathrm{Hf}$ was made following a method detailed in Fisher et al. (2011). For Yb, the interference-free ${ }^{171} \mathrm{Yb}$ was corrected for mass bias effects using an exponential law and ${ }^{173} \mathrm{Yb} /{ }^{171} \mathrm{Yb}=1.130172$ (Segal et al., 2003). The mass bias-corrected ${ }^{171} \mathrm{Yb}$ was monitored during the run and the magnitude of the ${ }^{176} \mathrm{Yb}$ interference on ${ }^{176} \mathrm{Hf}$ was calculated using ${ }^{176} \mathrm{Yb} /{ }^{171} \mathrm{Yb}=0.897145$ (Segal et al., 2003). For Lu, the interference-free ${ }^{175} \mathrm{Lu}$ was corrected for mass bias effects assuming $\beta \mathrm{Lu}=\beta \mathrm{Yb}$ and using an exponential law. The mass bias-corrected ${ }^{176} \mathrm{Lu}$ was monitored during the run and the magnitude of the ${ }^{176} \mathrm{Lu}$ interference on ${ }^{176} \mathrm{Hf}$ was calculated using ${ }^{176} \mathrm{Lu} /{ }^{175} \mathrm{Lu}=0.02655$ (Vervoort et al., 2004). Interference-corrected ${ }^{176} \mathrm{Hf} /{ }^{177} \mathrm{Hf}$ were corrected for mass bias using an exponential law and ${ }^{179} \mathrm{Hf} /{ }^{177} \mathrm{Hf}=0.7325$ (Patchett et al., 1981), and were finally normalized to JMC-475 $=0.282160$. The accuracy and long-term reproducibility of the measurements were gauged by analyzing two zircon reference standards: Plesovice $\left({ }^{176} \mathrm{Hf} /{ }^{177} \mathrm{Hf}=0.282472 \pm 21, \quad n=24\right) \quad$ and $\quad$ Mud Tank $\left({ }^{176} \mathrm{Hf} /{ }^{177} \mathrm{Hf}=0.282504 \pm 20, n=21\right.$ ) (all errors at 2 s.d. level).

\subsection{Oxygen isotopes}

Oxygen isotopes were measured on the CAMECA IMS1270 ion microprobe at the CRPG Nancy (France), using a method similar to that described in earlier reports (e.g., Martin et al., 2006, 2008), which is only briefly summarized below. $\mathrm{A} \mathrm{Cs}^{+}$primary beam of $c$. $5 \mathrm{nA}$ was used to sputter a $20 \mu \mathrm{m}$ rastered sample area. The negative secondary ions were measured at a mass resolution $(\mathrm{M} / \Delta \mathrm{M})$ of 2500 in multicollection mode on Faraday cups, with a counting rate of c. $2.910^{9} \mathrm{cps}$ on ${ }^{16} \mathrm{O}$, where each measurement consisted of 15 counting cycles of $10 \mathrm{~s}$. Oxygen isotope data were normalized to measurements of the Temora zircon standard and are reported with reference to SMOW assuming a $\delta^{18} \mathrm{O}$ value of $8.2 \%$ for this standard (Black et al., 2004).

\section{Results}

\subsection{Morphology and major elements}

Observed under binocular microscope, the zircon megacryst is euhedral to subhedral, with a pronounced oscillatory zoning, visible under natural light (Fig. 2B). In particular, two well marked growth bands are observed in the upper part of the crystal. The grain displays numerous fractures and cracks, some of which cutting across the whole crystal. In the central part of the grain, some of these fractures are connected with the matrix and are filled with K-feldspar (see EPMA analyses in Table 1). The grain is partly wrapped by a band, which appears translucent in natural light and dark in polarized light. This band now corresponds to a void and is particularly well visible at the upper and lower terminations. Where this band is present, the limits of the grain appear ragged (in particular see the lower part of the grain), which suggests a grain boundary modification during fluid interaction. The central fracture, filled with K-feldspar, is connected to this band, suggesting that the latter was initially filled with the same feldspathic material. In its left upper part (see enlargement of Fig. 2C), the crystal is made of a zone surrounded by a network of radial fractures, which resembles a fractured rim. In contrast, in its left lower part, the crystal is in sharp contact with K-feldspar, which seems to engulf it. EPMA analyses were determined on the different domains of the megacryst in order to characterize major element variations (see Fig. $3 \mathrm{~A}$ and Table 1 ). Overall, the $\mathrm{SiO}_{2}$ and $\mathrm{ZrO}_{2}$ contents show no significant variations with values close to stoichiometry for both elements $\left(\mathrm{SiO}_{2}=31.06 \pm 0.42 \mathrm{wt} \%\right.$ and $\left.\mathrm{Zr}_{2} \mathrm{O}=65.76 \pm 0.88 \mathrm{wt} \%\right)$ especially if considering $\mathrm{Hf}$ substitution (mean $\mathrm{HfO}_{2}$ values of $1.68 \mathrm{wt} \%$ ) to the zircon lattice. The most important variations are observed for 
Table 1

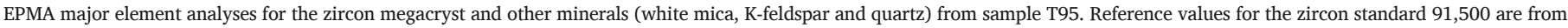
Wiedenbeck et al., 2004. Structural formulas for K-Feldspar and White-Micas are available in Appendix.

\begin{tabular}{|c|c|c|c|c|c|c|c|c|c|c|c|c|c|c|c|c|}
\hline Point & $\mathrm{Al}_{2} \mathrm{O}_{3}$ & $\mathrm{SiO}_{2}$ & $\mathrm{TiO}_{2}$ & $\mathrm{Na}_{2} \mathrm{O}$ & $\mathrm{MgO}$ & $\mathrm{MnO}$ & $\mathrm{FeO}$ & $\mathrm{HfO}_{2}$ & $\mathrm{CaO}$ & $\mathrm{K}_{2} \mathrm{O}$ & $\mathrm{P}_{2} \mathrm{O}_{5}$ & $\mathrm{Y}_{2} \mathrm{O}_{3}$ & $\mathrm{ZrO}_{2}$ & $\mathrm{UO}_{2}$ & Total & $\delta 180$ \\
\hline & $\mathrm{wt} \%$ & wt $\%$ & wt $\%$ & wt $\%$ & wt $\%$ & wt $\%$ & wt $\%$ & wt $\%$ & wt $\%$ & $\mathrm{wt} \%$ & wt $\%$ & wt $\%$ & wt $\%$ & wt $\%$ & & \\
\hline \multicolumn{17}{|c|}{$91,500(n=6)$} \\
\hline this study & - & 32.29 & - & - & - & - & - & 0.76 & - & - & 0.004 & 0.011 & 66.1702 & - & 99.2 & \\
\hline Reference & - & 32.69 & - & - & - & - & - & 0.70 & - & - & 0.016 & 0.016 & 66.18 & 0.010 & 99.6 & \\
\hline \multicolumn{17}{|l|}{ Zircon } \\
\hline $5 / 1$ & - & 30.94 & - & - & 0.01 & 0.01 & 0.00 & 1.55 & - & 0.01 & - & 0.38 & 64.94 & 0.11 & 98.0 & 9.1 \\
\hline $6 / 1$ & - & 30.63 & 0.03 & - & 0.00 & - & 0.02 & 1.57 & - & 0.01 & - & 0.56 & 65.43 & 0.15 & 98.4 & \\
\hline $7 / 1$. & - & 30.67 & 0.04 & - & - & 0.02 & 0.01 & 1.54 & - & 0.00 & - & 0.54 & 64.30 & 0.23 & 97.3 & \\
\hline $8 / 1$. & - & 30.93 & 0.02 & - & - & 0.01 & 0.00 & 1.96 & 0.01 & - & - & & 65.64 & - & 98.6 & 8.9 \\
\hline $9 / 1$ & - & 31.07 & 0.02 & - & - & - & 0.00 & 1.53 & 0.01 & 0.01 & - & 0.20 & 65.92 & 0.08 & 98.8 & \\
\hline $10 / 1$ & - & 31.18 & 0.00 & - & - & 0.01 & 0.02 & 1.77 & 0.02 & 0.01 & - & 0.55 & 65.23 & 0.16 & 99.0 & 10 \\
\hline $30 / 1$ & - & 30.97 & 0.03 & - & 0.01 & 0.04 & 0.00 & 1.45 & - & 0.01 & - & 0.05 & 66.73 & 0.04 & 99.3 & 7.1 \\
\hline $31 / 1$ & - & 31.07 & 0.02 & - & 0.00 & - & 0.01 & 1.54 & - & - & - & 0.19 & 66.03 & 0.13 & 99.0 & 9.1 \\
\hline $32 / 1$ & - & 31.17 & 0.00 & - & - & 0.02 & 0.03 & 1.57 & - & 0.01 & - & 0.06 & 66.80 & - & 99.7 & 7.6 \\
\hline $33 / 1$ & 0.00 & 31.28 & 0.03 & - & - & - & 0.00 & 1.43 & - & 0.00 & - & 0.20 & 66.30 & 0.13 & 99.4 & 10.4 \\
\hline $34 / 1$ & - & 31.33 & 0.01 & - & 0.00 & - & 0.01 & 1.56 & 0.00 & 0.01 & - & 0.29 & 66.43 & 0.08 & 99.7 & 10.6 \\
\hline $35 / 1$ & - & 31.07 & - & - & - & - & 0.00 & 1.69 & - & 0.03 & - & 0.28 & 66.20 & 0.12 & 99.4 & 10.1 \\
\hline $36 / 1$ & - & 30.99 & 0.01 & - & - & - & 0.01 & 1.49 & - & 0.01 & - & 0.13 & 66.15 & 0.02 & 98.8 & 9.4 \\
\hline $37 / 1$ & - & 30.95 & 0.01 & - & - & - & 0.02 & 1.51 & 0.02 & 0.01 & - & 0.15 & 65.52 & 0.11 & 98.3 & 8.9 \\
\hline $38 / 1$ & - & 31.11 & 0.02 & - & - & - & 0.01 & 1.67 & 0.02 & 0.01 & - & 0.40 & 65.71 & 0.16 & 99.1 & 10 \\
\hline $39 / 1$ & - & 31.24 & 0.01 & - & 0.01 & 0.03 & - & 1.58 & - & 0.01 & - & 0.18 & 66.19 & 0.05 & 99.3 & 11.5 \\
\hline $40 / 1$ & - & 30.92 & - & - & - & - & 0.01 & 1.63 & 0.02 & - & - & 0.37 & 66.07 & 0.09 & 99.1 & 11.2 \\
\hline $41 / 1$ & - & 31.29 & 0.01 & - & - & 0.02 & - & 1.60 & 0.01 & 0.01 & - & 0.42 & 66.04 & 0.09 & 99.5 & 10.2 \\
\hline 43/1. & - & 31.17 & 0.01 & - & 0.00 & - & 0.01 & 1.71 & 0.01 & - & - & 0.30 & 66.26 & 0.08 & 99.5 & \\
\hline $44 / 1$ & - & 31.32 & 0.02 & - & 0.01 & - & 0.01 & 1.57 & 0.02 & - & - & & 66.45 & - & 99.4 & 10.2 \\
\hline $45 / 1$ & - & 30.83 & 0.01 & - & - & 0.00 & 0.00 & 1.63 & 0.01 & 0.01 & - & 0.40 & 66.23 & 0.12 & 99.2 & 12.3 \\
\hline $46 / 1$ & - & 30.64 & 0.02 & - & - & - & 0.06 & 2.03 & 0.03 & 0.01 & - & 0.54 & 63.93 & 0.22 & 97.5 & 11.2 \\
\hline $47 / 1$ & - & 30.30 & 0.01 & - & - & 0.00 & 0.19 & 2.23 & 0.29 & 0.01 & - & 0.18 & 64.15 & 0.53 & 97.9 & 10.9 \\
\hline $48 / 1$ & 0.07 & 29.73 & 0.02 & - & - & 0.01 & 0.35 & 2.09 & 1.21 & 0.01 & - & 0.19 & 62.97 & 0.57 & 97.2 & 10.2 \\
\hline $49 / 1$ & 0.09 & 31.10 & - & - & - & - & 0.10 & 1.62 & 0.03 & 0.03 & - & 0.35 & 65.60 & 0.05 & 99.0 & \\
\hline $50 / 1$ & 0.00 & 31.42 & 0.02 & - & - & - & 0.01 & 1.81 & 0.02 & 0.01 & - & - & 66.23 & - & 99.5 & \\
\hline $51 / 1$ & 0.23 & 32.33 & 0.02 & - & - & 0.02 & 0.08 & 1.72 & 0.07 & 0.12 & - & - & 66.53 & - & 101.1 & \\
\hline $52 / 1$ & 0.00 & 31.58 & - & - & 0.01 & - & 0.03 & 2.02 & 0.00 & - & - & - & 66.39 & - & 100.0 & \\
\hline $56 / 1$ & - & 31.18 & - & - & - & - & 0.01 & 1.70 & 0.01 & 0.00 & - & 0.32 & 65.65 & 0.06 & 98.9 & 10 \\
\hline $55 / 1$ & 0.01 & 31.05 & - & - & - & - & $->$ & 1.69 & - & 0.02 & - & 0.28 & 65.52 & 0.03 & 98.6 & 9.8 \\
\hline $57 / 1$ & - & 31.28 & - & - & - & - & 0.00 & 1.79 & 0.03 & - & - & & 66.92 & - & 100.0 & 10.1 \\
\hline $58 / 1$ & - & 31.02 & 0.00 & - & - & - & 0.01 & 1.64 & 0.01 & 0.00 & - & 0.32 & 65.80 & 0.08 & 98.9 & 11.1 \\
\hline \multicolumn{17}{|l|}{ White mica } \\
\hline $12 / 1$ & 31.47 & 45.77 & 1.00 & 0.48 & 2.19 & - & 1.14 & - & - & 10.78 & - & - & 0.01 & - & 92.8 & \\
\hline $13 / 1$ & 31.78 & 45.93 & 0.95 & 0.49 & 2.02 & - & 1.06 & 0.02 & 0.02 & 10.97 & 0.01 & - & - & - & 93.3 & \\
\hline $14 / 1$ & 31.22 & 46.82 & 1.12 & 0.52 & 2.30 & - & 1.15 & - & - & 10.99 & 0.00 & - & 0.00 & - & 94.1 & \\
\hline 15/1. & 30.84 & 47.65 & 1.05 & 0.40 & 2.30 & - & 0.88 & - & 0.04 & 10.93 & 0.01 & - & 0.01 & - & 94.1 & \\
\hline $16 / 1$ & 31.96 & 47.07 & 1.00 & 0.39 & 1.91 & - & 0.82 & 0.00 & 0.02 & 11.19 & 0.03 & - & 0.00 & - & 94.4 & \\
\hline $17 / 1$ & 30.89 & 46.88 & 1.01 & 0.43 & 2.32 & 0.01 & 1.03 & 0.04 & 0.01 & 11.08 & 0.01 & - & 0.00 & - & 93.7 & \\
\hline $20 / 1$ & 31.90 & 47.19 & 0.78 & 0.44 & 1.97 & - & 0.87 & - & 0.00 & 11.22 & 0.01 & - & - & - & 94.4 & \\
\hline $53 / 1$ & 33.90 & 45.78 & 0.93 & 0.48 & 1.30 & - & 0.75 & - & 0.01 & 11.38 & 0.01 & - & 0.02 & - & 94.6 & \\
\hline $54 / 1$ & 31.91 & 46.75 & 0.63 & 0.47 & 2.04 & 0.00 & 0.85 & 0.00 & 0.01 & 11.12 & 0.01 & - & 0.01 & - & 93.8 & \\
\hline \multicolumn{17}{|l|}{ K-Feldspar } \\
\hline $11 / 1$ & 18.86 & 62.01 & - & 1.25 & 0.01 & 0.00 & 0.01 & 0.01 & 0.03 & 15.71 & - & - & 0.02 & - & 97.9 & \\
\hline $18 / 1$ & 18.77 & 62.13 & 0.02 & 1.35 & 0.00 & 0.02 & 0.05 & - & 0.05 & 15.73 & 0.03 & - & - & - & 98.2 & \\
\hline 19/1. & 18.86 & 62.42 & 0.02 & 1.27 & - & 0.02 & 0.02 & - & 0.01 & 15.61 & - & - & - & - & 98.2 & \\
\hline $21 / 1$ & 19.09 & 62.31 & 0.01 & 1.15 & 0.00 & 0.01 & 0.02 & 0.06 & 0.03 & 15.83 & 0.03 & - & 0.02 & - & 98.5 & \\
\hline $22 / 1$ & 18.58 & 61.30 & - & 1.69 & - & - & - & - & 0.03 & 14.98 & 0.02 & - & - & - & 96.6 & \\
\hline $26 / 1$ & 18.59 & 62.61 & 0.03 & 1.08 & - & - & 0.00 & - & - & 16.08 & - & - & - & - & 98.4 & \\
\hline $42 / 1$ & 18.72 & 61.47 & 0.01 & 0.87 & 0.01 & - & 0.01 & 0.08 & 0.02 & 16.07 & 0.00 & - & - & - & 97.3 & \\
\hline \multicolumn{17}{|l|}{ Quartz } \\
\hline $23 / 1$ & 0.03 & 97.72 & - & - & - & 0.02 & 0.01 & - & - & 0.02 & - & - & 0.03 & 0.01 & 97.8 & \\
\hline $24 / 1$ & 0.02 & 98.33 & 0.03 & 0.01 & 0.00 & - & - & - & - & - & 0.01 & - & 0.01 & - & 98.4 & \\
\hline $25 / 1$ & - & 98.34 & 0.01 & 0.02 & - & 0.01 & - & 0.01 & 0.01 & 0.01 & 0.01 & - & - & - & 98.4 & \\
\hline
\end{tabular}


Table 2

LA-ICP-MS trace element analyses for the zircon megacryst and rutile from sample T95.

\begin{tabular}{|c|c|c|c|c|c|c|c|c|c|c|c|c|c|c|c|c|c|c|c|c|}
\hline & 91,500 & & Reference & T95 Zirc & n Megacrys & & & & & & & & & & & & Rutile & & & \\
\hline Element & $(\mathrm{n}=9)$ & $\pm(\mathrm{sd})$ & values & $\# 1$ & $\# 2$ & $\# 3$ & $\# 4$ & $\# 5$ & $\# 6$ & $\# 7$ & $\# 8$ & $\# 9$ & $\# 10$ & $\# 11$ & $\# 12$ & $\# 13$ & $\# 14$ & $\# 15$ & $\# 16$ & $\# 17$ \\
\hline $\mathrm{Si}$ & & & & istd & istd & istd & istd & istd & istd & istd & istd & istd & istd & istd & istd & istd & 65.4 & 1.1 & 168.9 & 398.5 \\
\hline $\mathrm{P}$ & & & & - & - & - & - & - & 295 & 272 & 262 & 268 & 253 & 110 & 165 & 160 & 1.1 & 37.1 & 15.9 & 27.1 \\
\hline $\mathrm{Ti}$ & 5.84 & 0.43 & & 18.6 & 16.7 & 20.0 & 18.9 & 16.6 & 22.9 & 20.0 & 25.5 & 17.9 & 16.9 & 7.3 & 6.9 & 7.7 & istd & istd & istd & istd \\
\hline $\mathrm{v}$ & & & & - & - & - & - & - & - & - & - & - & - & - & 0.116 & 0.946 & 2028 & 1393 & 1495 & 1745 \\
\hline $\mathrm{Cr}$ & & & & - & - & - & - & - & - & - & - & - & - & - & - & - & 7.92 & 28.34 & 9.27 & 69.52 \\
\hline $\mathrm{Rb}$ & 0.051 & 0.035 & & 0.57 & 0.65 & 0.54 & 0.60 & 0.48 & 0.96 & 0.94 & 0.83 & 0.83 & 0.63 & 0.21 & - & - & - & - & - & - \\
\hline $\mathrm{Sr}$ & 0.077 & 0.022 & 0.052 & - & - & - & - & - & 1.18 & 0.96 & 1.02 & 0.81 & 0.88 & 0.33 & - & 0.35 & 1.24 & 2.52 & 1.72 & 1.51 \\
\hline $\mathrm{Y}$ & 132.8 & 5.8 & 140.0 & 2936 & 2782 & 2554 & 2649 & 2822 & 3709 & 3436 & 3124 & 3358 & 2196 & 658 & 766 & 907 & 0.143 & 2.49 & 0.242 & 0.038 \\
\hline $\mathrm{Zr}$ & & & & - & - & - & - & - & - & - & - & - & - & - & - & - & 549.11 & 738.81 & 628.73 & 493.17 \\
\hline $\mathrm{Nb}$ & 0.913 & 0.096 & 0.79 & 2.72 & 2.45 & 2.39 & 2.291 & 2.38 & 4.21 & 3.49 & 3.81 & 3.25 & 2.43 & 1.23 & 1.09 & 1.38 & 7038 & 5837 & 4234 & 2898 \\
\hline Mo & & & & 1.1 & 1.2 & 1.0 & 1.1 & 1.2 & 1.5 & 1.6 & 1.5 & 1.7 & 1.7 & 1.7 & - & - & - & - & - & - \\
\hline $\mathrm{Ba}$ & 0.037 & 0.016 & 0.06 & - & 0.15 & 0.42 & 1.42 & 0.37 & 0.05 & 0.06 & 0.19 & 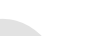 & 0.32 & 0.02 & - & 0.552 & - & - & - & - \\
\hline $\mathrm{La}$ & 0.0048 & 0.0026 & 0.006 & - & 0.0051 & 0.0269 & 0.0033 & 0.0104 & 0.0068 & 0.0035 & 0.0126 & 0.0039 & 0.0083 & 0.0067 & - & 0.626 & - & - & - & - \\
\hline $\mathrm{Ce}$ & 2.33 & 0.13 & 2.56 & 0.682 & 0.744 & 0.749 & 0.779 & 0.734 & 0.454 & 0.538 & 0.532 & 0.379 & 0.695 & 0.149 & 0.116 & 5.48 & - & - & - & - \\
\hline $\operatorname{Pr}$ & 0.0098 & 0.0033 & 0.024 & 0.0016 & 0.0038 & 0.0292 & 0.011 & 0.0227 & 0.0058 & 0.0025 & 0.0057 & 0.0016 & 0.006 & 0.0073 & 0.0096 & 0.57 & - & - & - & - \\
\hline $\mathrm{Nd}$ & 0.235 & 0.05 & 0.24 & 0.096 & 0.085 & 0.155 & 0.143 & 0.226 & 0.225 & 0.226 & 0.167 & 0.227 & 0.218 & 0.137 & 0.106 & 3.84 & - & - & - & - \\
\hline $\mathrm{Sm}$ & 0.486 & 0.055 & 0.50 & 1.67 & 1.41 & 1.47 & 1.46 & 1.54 & 1.5 & 1.64 & 1.341 & 1.294 & 1.24 & 0.317 & 0.239 & 4.02 & - & - & - & - \\
\hline $\mathrm{Eu}$ & 0.218 & 0.021 & 0.24 & 2.42 & 2.57 & 1.869 & 2.31 & 2.42 & 2.42 & 2.52 & 2.275 & 2.157 & 1.646 & 0.373 & 0.366 & 1.57 & - & - & - & - \\
\hline $\mathrm{Gd}$ & 1.89 & 0.15 & 2.21 & 28.98 & 28.44 & 24.02 & 25.52 & 27.95 & 17.82 & 18.26 & 17.32 & 17.86 & 12.93 & 2.79 & 4.6 & 14.41 & - & - & - & - \\
\hline $\mathrm{Tb}$ & 0.792 & 0.064 & 0.86 & 15.69 & 14.93 & 13.47 & 14.22 & 15.23 & 16.77 & 17.04 & 15.74 & 16.26 & 11.4 & 2.78 & 2.94 & 5.29 & - & - & - & - \\
\hline Dy & 10.83 & 0.82 & 11.8 & 239 & 221 & 201 & 208 & 229 & 285 & 276 & 253 & 270 & 186 & 50 & 47.55 & 69.46 & - & - & - & - \\
\hline Ho & 4.94 & 0.23 & 4.84 & 92 & 85 & 79 & 81 & 88 & 109 & 103 & 95 & 100 & 71 & 20 & 21.12 & 27.18 & - & - & - & - \\
\hline $\mathrm{Er}$ & 23.73 & 1.26 & 24.6 & 423 & 395 & 367 & 379 & 405 & 516 & 481 & 436 & 448 & 318 & 102 & 116.21 & 140.92 & - & - & - & - \\
\hline $\mathrm{Tm}$ & 6.89 & 0.39 & 6.89 & 88 & 84 & 77 & 81 & 85 & 135 & 122 & 111 & 111 & 84 & 29 & 28 & 32.79 & - & - & - & - \\
\hline $\mathrm{Yb}$ & 68.50 & 7.76 & 73.9 & 805 & 768 & 708 & 747 & 780 & 1548 & 1368 & 1231 & 1205 & 945 & 346 & 292 & 317 & - & - & - & - \\
\hline $\mathrm{Lu}$ & 12.93 & 0.64 & 13.1 & 152 & 145 & 135 & 143 & 147 & 181 & 164 & 149 & 142 & 115 & 44 & 59 & 62 & - & - & - & - \\
\hline $\mathrm{Hf}$ & 5601 & 197 & 5895 & 10,561 & 10,257 & 9718 & 10,142 & 10,175 & 11,008 & 11,002 & 11,015 & 10,845 & 10,458 & 12,658 & 13,944 & 10,542 & 31.29 & 44.65 & 30.65 & 21.5 \\
\hline $\mathrm{Ta}$ & 0.49 & 0.04 & & 2.23 & 2.02 & 1.95 & 2.03 & 1.88 & 3.75 & 3.42 & 3.56 & 3.47 & 2.17 & 1.26 & 0.929 & 0.585 & 231 & 231 & 53 & 108 \\
\hline $\mathrm{Pb}^{*}$ & 15.3 & 0.5 & & 134.3 & 125.0 & 120.9 & 120.6 & 120.4 & 137.2 & 136.9 & 118.3 & 124.0 & 108.2 & 30.8 & 32.3 & 43.9 & - & - & - & - \\
\hline Th & 23.1 & 1.2 & 29.9 & 0.62 & 0.80 & 0.81 & 0.86 & 0.81 & 0.64 & 0.38 & 0.43 & 0.20 & 2.83 & 0.57 & 0.155 & 1.17 & - & 0.05 & - & - \\
\hline $\mathrm{U}$ & 72.0 & 3.9 & 80.0 & 1201 & 1117 & 1078 & 1107 & 1118 & 1285 & 1284 & 1100 & 1150 & 1028 & 300 & 310 & 404 & 20.3 & 7.8 & 24.4 & 28.65 \\
\hline Ti-in-Zr $\left({ }^{\circ} \mathrm{C}\right)$ & & & & 808 & 796 & 816 & 809 & 796 & 830 & 815 & 842 & 804 & 798 & 717 & 712 & 722 & 695 & 722 & 707 & 685 \\
\hline $\mathrm{Nb} / \mathrm{Ta}$ & & & & 1.2 & 1.2 & 1.2 & 1.1 & 1.3 & 1.1 & 1.0 & 1.1 & 0.9 & 1.1 & 1.0 & 1.2 & 2.4 & 30.5 & 25.2 & 79.5 & 26.8 \\
\hline $\mathrm{Th} / \mathrm{U}$ & & & & 0.0005 & 0.0007 & 0.0008 & 0.0008 & 0.0007 & 0.0005 & 0.0003 & 0.0004 & 0.0002 & 0.0028 & 0.0019 & 0.0005 & 0.0029 & - & 0.006 & - & - \\
\hline Y/Ho & & & & 32.0 & 32.7 & 32.4 & 32.5 & 32.1 & 34.2 & 33.3 & 32.9 & 33.7 & 31.1 & 32.7 & 36.3 & 33.4 & & & & \\
\hline $\mathrm{Yb} / \mathrm{Gd})_{\mathrm{N}}$ & & & & 34.3 & 33.4 & 36.4 & 36.2 & 34.5 & 107.4 & 92.6 & 87.8 & 83.4 & 90.4 & 153.4 & 78.5 & 27.2 & & & & \\
\hline LaN & & & & - & 0.022 & 0.114 & 0.014 & 0.044 & 0.029 & 0.015 & 0.053 & 0.016 & 0.035 & 0.028 & - & 2.641 & & & & \\
\hline $\left.\mathrm{EuN} / \mathrm{Eu}^{*}\right)_{\mathrm{N}}$ & & & & 1.06 & 1.24 & 0.96 & 1.15 & 1.12 & 1.43 & 1.40 & 1.44 & 1.37 & 1.25 & 1.21 & 1.06 & 0.63 & & & & \\
\hline$\sum$ REE & & & & 1848 & 1745 & 1609 & 1684 & 1782 & 2813 & 2555 & 2311 & 2314 & 1747 & 598 & 572 & 685 & & & & \\
\hline
\end{tabular}

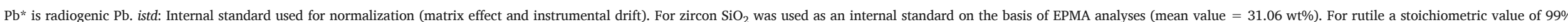

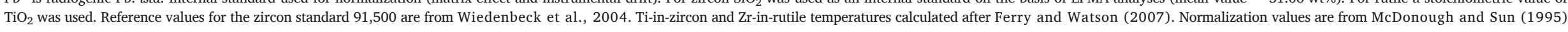



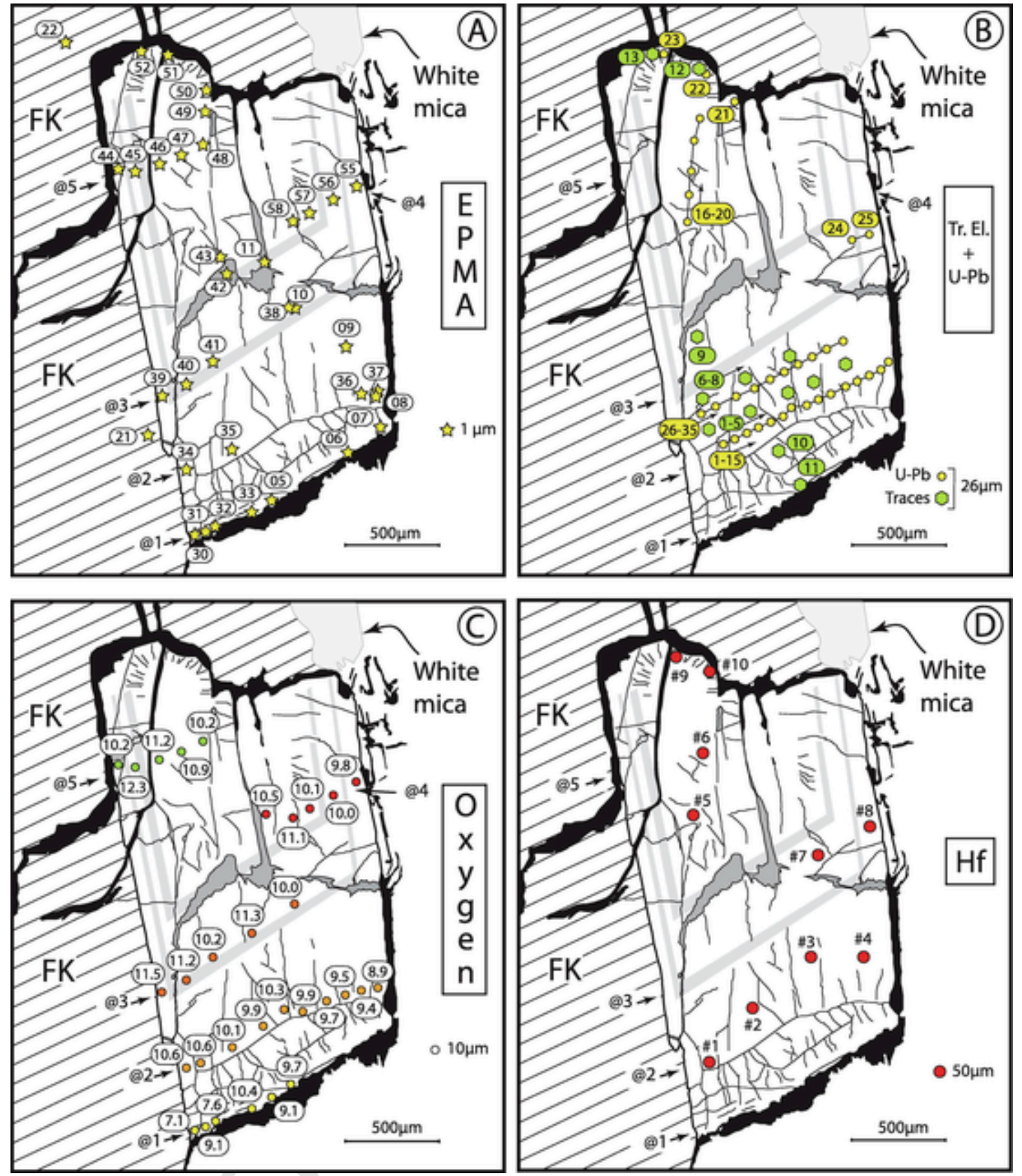

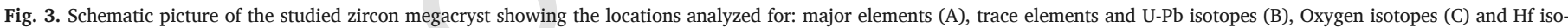
topes (D). Numbers in (A) correspond to analyses in Table 1, in (B) to analyses in Table 2 and 3 and in (D) to analyses in Table 5 . Numbers in (C) correspond to 8180 values.

$\mathrm{HfO}_{2}$ and $\mathrm{Y}_{2} \mathrm{O}_{3}$, which range from 1.43 to $2.23 \mathrm{wt} \%$ and from below detection limit to $0.56 \mathrm{wt} \%$ respectively. Other measured elements are generally below detection limit except $\mathrm{U}$, which displays a range of $\mathrm{UO}_{2}$ contents from $0.02 \mathrm{wt} \%$ to $0.57 \mathrm{wt} \%$. It is noteworthy that the highest $\mathrm{UO}_{2}$ contents (from 0.22 to $0.57 \mathrm{wt} \%$ ) are measured in the left upper part of the crystal, which is surrounded by the fractured zone, thus suggesting that the radial fractures were caused by volume expansion due to metamictisation of a U-rich zone. This zone also displays elevated concentrations in non-formula elements such as Fe and Ca (see analyses 46-49 in Table 1). Microprobe analyses of the main mineral phases (K-feldspar, white mica and quartz) observed throughout the thin section were also investigated. The large white mica flakes (see Table 1) provide low phengitic substitution values of $\mathrm{Si}=3.09-3.22$ apfu (mean value of 3.16 apfu on 9 analy- ses), but high Ti content between 0.032 and 0.057 apfu. The low $\mathrm{Si}$ contents of these K-white micas contrast with those of phengite from HP assemblages (e.g., Bukala et al., 2018) and may be taken as evidence that the pressures under which they crystallized were lower than high-pressure conditions. However, recent studies have shown that the Si content in phengite is not, by itself, as reliable as commonly assumed, especially in Ti-rich phengite (Auzanneau et al., 2010; Nahodilova et al., 2014). The large K-feldspar encircling the zircon megacryst (analyses 21 and 22 in Table 1) corresponds to Or $_{85-90}$, consistent with other analyses in the thin section $\left(\mathrm{Or}_{88-91}\right)$, which is not significantly different from feldspathic material filling fractures within the zircon megacryst (Or 89 -92, analyses 11 and 42 in Table 1 ) and cutting across both the large K-feldspar and the zircon megacryst. 


\subsection{Trace elements signature}

Trace element analyses were performed mainly in the inner part of the megacryst (10 spots), broadly along two transects perpendicular to the main growth axis and parallel to the transects selected for U-Pb and $\mathrm{O}$ analyses (Fig. 3B). Although heavily fractured, the upper rim was also investigated for trace elements ( 2 spots) as well as the southern edge of the grain (1 spot).

The inner part of the crystal (see Table 2) yields high $U$ contents $($ mean $=1147 \mathrm{ppm})$ and low Th contents $($ mean $=0.84 \mathrm{ppm})$ resulting in very low $\mathrm{Th} / \mathrm{U}$ ratios (mean $=0.0008$ ). The REE patterns (Fig. 4) are characterized by low La contents $\left(\mathrm{La}_{\mathrm{N}}=10^{-1}-10^{-2}\right)$, pronounced positive $\mathrm{Ce}$ anomalies and no significant $\mathrm{Eu}$ anomalies $\left(\mathrm{Eu}_{\mathrm{N}} / \mathrm{Eu}^{*}{ }_{\mathrm{N}}=0.96-1.44\right)$. The HREE patterns are steep $\left(\mathrm{Yb}_{\mathrm{N}} / \mathrm{Gd}_{\mathrm{N}}=33-107\right)$ and overall, not different from those typically displayed by magmatic zircons (Barth and Wooden, 2010). The Ti content of the ten spots ranges from 16.7 to $25.5 \mathrm{ppm}$, which indicates crystallization in the temperature interval $796-842{ }^{\circ} \mathrm{C}$ (calculated after Ferry and Watson, 2007) and, when attributing an individual error of $\pm 25^{\circ} \mathrm{C}$, results in a mean value of $811 \pm 15^{\circ} \mathrm{C}(\mathrm{MSWD}=0.37$; $\mathrm{n}=10)$.

Three analyses were performed close to the edge of the megacryst, one close to its lower termination (\#11) and two in the fractured rim visible in the upper tip of the megacryst (\#12 and \#13). Compared to the inner part (see Table 2), these analyses are significantly depleted in $\mathrm{Nb}$ (1.09-1.38 versus $2.29-4.21 \mathrm{ppm})$, Ta (0.59-1.26 versus 1.88-3.75 ppm), Y (658-910 ppm versus 2196-3709 ppm) and $\sum$ REE (570-690 ppm versus $1600-2800 \mathrm{ppm}$ ). They display very low $\mathrm{Th} / \mathrm{U}$ (0.0005-0.003) similar to those measured in the inner part, but the $\mathrm{U}$ content is much lower (300-404 ppm versus $1147 \mathrm{ppm}$ on average). HREE patterns have similar $\left(\mathrm{Yb} / \mathrm{Gd}_{\mathrm{N}}=78-153\right.$, \#12 and \#13) to weaker slope $\left(\mathrm{Yb} / \mathrm{Gd}_{\mathrm{N}}=27, \# 11\right)$ with a less pronounced positive Ce anomaly. It is worth noting that one analysis of the northern rim displays the highest LREE content and the weaker positive Ce anomaly. The three analyses display low Ti contents ranging from 6.9 to $7.7 \mathrm{ppm}$, which translate to a temperature of $717 \pm 28{ }^{\circ} \mathrm{C}$.

\section{3. $U$-Pb dating}

$\mathrm{U}-\mathrm{Pb}$ laser spot analyses were conducted in the inner part of the crystal along two transverses (15 and 10 spots respectively) perpendicular to the main growth axis (see Fig. 3B) and nine spots were performed in the upper part of the grain, including three spots in the fractured rim visible in the upper tip, and five spots in the high $\mathrm{U}$ zone in the center of the megacryst. U-Pb analyses (see Table 3 ) yield slightly discordant results (discordance ranges from +14 to $-2 \%$ ) which are attributed to the high $\mathrm{U}$ contents (mean of $1060 \mathrm{ppm}$ on 29 analyses). Interestingly, all analyses plot along a discordia line (Fig. 5) which has an upper intercept of $645 \pm 12 \mathrm{Ma}(\mathrm{MSWD}=0.3$ ) and a lower intercept which, although the result of a long extrapolation, is not significantly different from zero $(-144 \pm 220 \mathrm{Ma})$. The twenty-nine analyses have identical ${ }^{207} \mathrm{~Pb} /{ }^{206} \mathrm{~Pb}$ ratios, and since the lower intercept of the discordia line is close to zero, it is reasonable to calculate a weighted mean age of $654 \pm 5 \mathrm{Ma}$ (MSWD $=0.4 ; \mathrm{n}=29$ ), which is interpreted as our best estimate for crystallization of the zircon megacryst.

Although heavily fractured, the rim was also investigated for U-Pb. The five data points have low U contents, ranging from 46 to 365 ppm, and in the Concordia diagram (Fig. 5) they define a concordia age of $584 \pm 6 \mathrm{Ma}$ (MSWD of concordance $=3.9 ; \mathrm{n}=5$ ), that we attribute to crystallization of the rim.

\subsection{Hf and $\mathrm{O}$ isotopes}

Oxygen isotope analyses were performed along five transects perpendicular to the main growth axis (see Fig. 3C) and the results are reported in Table 4. Overall, the $O$ isotope values display very large intra-grain variations and range from 7.1 to $12.3 \%$ relative to SMOW. The lowest values are observed close to the southern termination of the crystal $\left(\delta^{18} \mathrm{O}=7.1 \%\right.$ and $7.6 \%$ for $\# 1$ and $\# 3$ of profile @1) or close to the right border $\left(\delta^{18} \mathrm{O}=8.9 \%\right.$ 。 for $\# 10$ of profile @2). These low $\delta^{18} \mathrm{O}$ values were obtained from area close to the feldspathic band fringing the zircon megacryst. From a general point of view, there is a broad tendency for $\delta^{18} \mathrm{O}$ values to decrease from

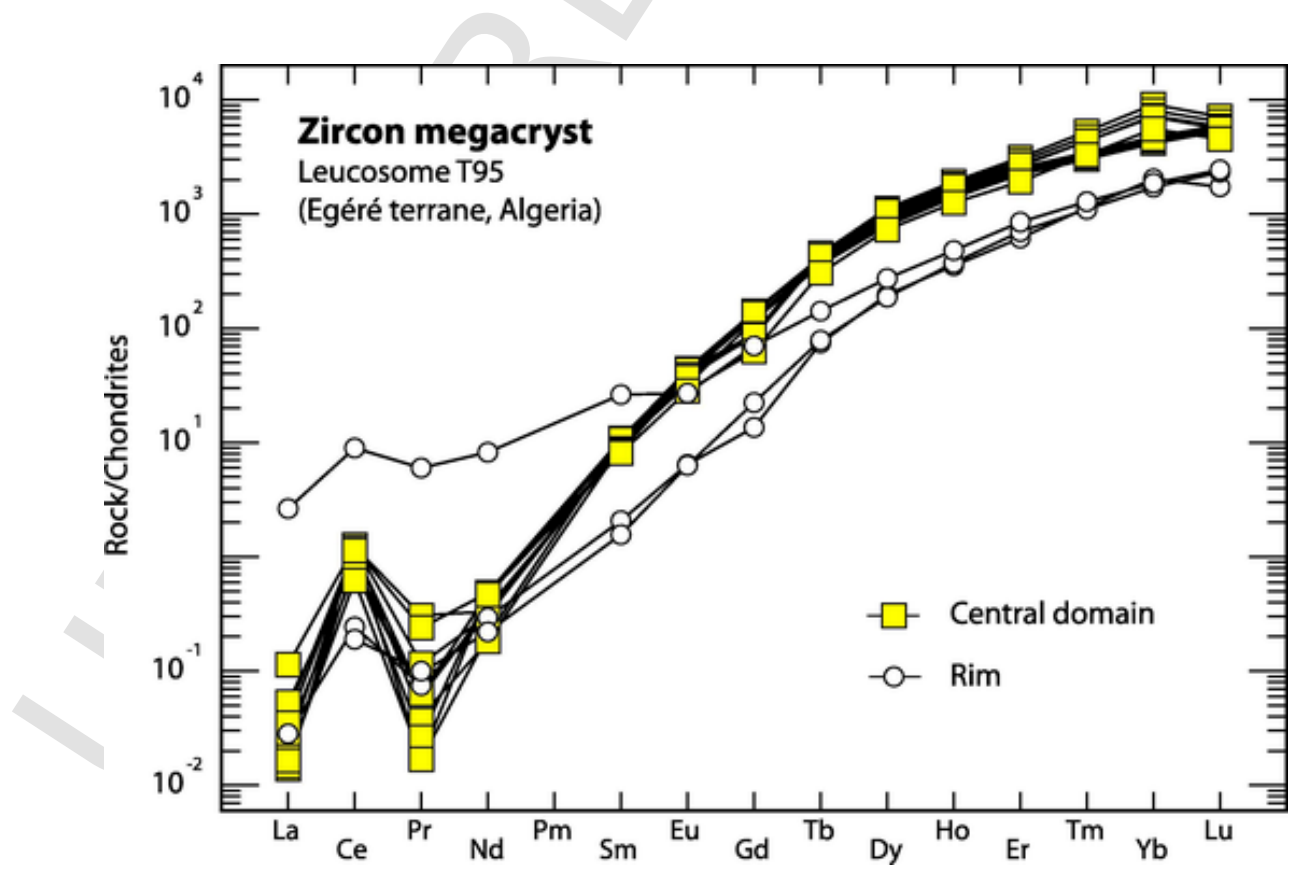

Fig. 4. Chondrite normalized rare earth element (REE) patterns for zircon domains analyzed in the megacryst. Normalization values from McDonough and Sun (1995). 
Table 3

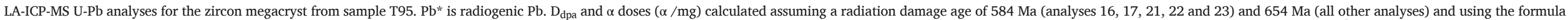
of Meldrum et al. (1998).

\begin{tabular}{|c|c|c|c|c|c|c|c|c|c|c|c|c|c|c|c|c|c|c|c|}
\hline Sample & $\mathrm{Pb}^{*}$ & Th & $\mathrm{U}$ & Th/ & $208 \mathrm{~Pb} /$ & $207 \mathrm{~Pb} /$ & \pm & $207 \mathrm{~Pb} /$ & \pm & $206 \mathrm{~Pb} /$ & \pm & Rho & Apparen & es (Ma) & & & Conc. & & \\
\hline & (ppm) & (ppm) & $(\mathrm{ppm})$ & $\mathrm{U}$ & $206 \mathrm{~Pb}$ & $206 \mathrm{~Pb}$ & $(1 \sigma)$ & $235 \mathrm{U}$ & $(1 \sigma)$ & $238 \mathrm{U}$ & $(1 \sigma)$ & & $206 \mathrm{~Pb} /$ & \pm & $207 \mathrm{~Pb} /$ & \pm & (\%) & Ddpa & alpha decay \\
\hline & & & & & & & & & & & & & $238 \mathrm{U}$ & $(1 \sigma)$ & $206 \mathrm{~Pb}$ & $(1 \sigma)$ & & & event/mg \\
\hline T95_1 & 86 & 0.670 & 909 & 0.00 & 0.000 & 0.0611 & 0.0004 & 0.8350 & 0.0142 & 0.0991 & 0.0016 & 0.94 & 609.1 & 9.3 & 643.4 & 12.6 & 94.7 & 0.091 & $2.52 \mathrm{E}+15$ \\
\hline T95_2 & 92 & 0.830 & 979 & 0.00 & 0.001 & 0.0614 & 0.0004 & 0.8212 & 0.0141 & 0.0971 & 0.0016 & 0.94 & 597.2 & 9.2 & 651.8 & 12.8 & 91.6 & 0.098 & $2.71 E+15$ \\
\hline T95_3 & 80 & 0.616 & 856 & 0.00 & 0.000 & 0.0615 & 0.0003 & 0.8226 & 0.0137 & 0.0970 & 0.0016 & 0.96 & 596.7 & 9.1 & 657.3 & 9.6 & 90.8 & 0.086 & $2.37 \mathrm{E}+15$ \\
\hline T95_4 & 81 & 0.813 & 889 & 0.00 & 0.001 & 0.0614 & 0.0004 & 0.8059 & 0.0132 & 0.0953 & 0.0015 & 0.94 & 586.6 & 8.6 & 651.7 & 12.4 & 90.0 & 0.089 & $2.46 \mathrm{E}+15$ \\
\hline T95_5 & 74 & 0.623 & 824 & 0.00 & 0.000 & 0.0613 & 0.0003 & 0.8879 & 0.0101 & 0.1051 & 0.0010 & 0.87 & 644.4 & 6.1 & 648.3 & 11.8 & 99.4 & 0.082 & $2.28 \mathrm{E}+15$ \\
\hline T95_6 & 81 & 0.904 & 903 & 0.00 & 0.002 & 0.0616 & 0.0003 & 0.8192 & 0.0113 & 0.0965 & 0.0012 & 0.92 & 593.8 & 7.1 & 659.3 & 11.8 & 90.1 & 0.090 & $2.50 \mathrm{E}+15$ \\
\hline T95_7 & 79 & 1.134 & 885 & 0.00 & 0.001 & 0.0610 & 0.0003 & 0.8924 & 0.0078 & 0.1061 & 0.0007 & 0.76 & 650.3 & 4.1 & 638.6 & 12.1 & 101.8 & 0.088 & $2.45 \mathrm{E}+15$ \\
\hline T95_-8 & 89 & 0.927 & 992 & 0.00 & 0.000 & 0.0611 & 0.0003 & 0.8072 & 0.0118 & 0.0959 & 0.0013 & 0.92 & 590.2 & 7.6 & 641.6 & 11.9 & 92.0 & 0.099 & $2.75 E+15$ \\
\hline T95_9 & 88 & 0.953 & 998 & 0.00 & 0.000 & 0.0617 & 0.0004 & 0.8023 & 0.0098 & 0.0944 & 0.0010 & 0.88 & 581.3 & 6.0 & 662.3 & 12.6 & 87.8 & 0.100 & $2.77 \mathrm{E}+15$ \\
\hline T95_10 & 94 & 1.124 & 1082 & 0.00 & 0.000 & 0.0617 & 0.0003 & 0.7959 & 0.0106 & 0.0936 & 0.0011 & 0.91 & 576.6 & 6.7 & 663.3 & 11.8 & 86.9 & 0.108 & $3.00 \mathrm{E}+15$ \\
\hline T95_11 & 91 & 0.927 & 1012 & 0.00 & 0.002 & 0.0617 & 0.0003 & 0.8364 & 0.0093 & 0.0982 & 0.0010 & 0.91 & 604.1 & 5.8 & 665.4 & 10.0 & 90.8 & 0.101 & $2.80 \mathrm{E}+15$ \\
\hline T95_12 & 95 & 0.959 & 1063 & 0.00 & 0.001 & 0.0615 & 0.0003 & 0.8225 & 0.0081 & 0.0970 & 0.0008 & 0.87 & 596.6 & 4.9 & 657.6 & 10.3 & 90.7 & 0.106 & $2.94 \mathrm{E}+15$ \\
\hline T95_13 & 95 & 1.028 & 1126 & 0.00 & 0.000 & 0.0614 & 0.0003 & 0.8097 & 0.0098 & 0.0956 & 0.0011 & 0.91 & 588.6 & 6.2 & 654.2 & 10.8 & 90.0 & 0.112 & $3.12 \mathrm{E}+15$ \\
\hline T95_14 & 94 & 0.969 & 1062 & 0.00 & 0.000 & 0.0615 & 0.0003 & 0.8192 & 0.0075 & 0.0966 & 0.0007 & 0.82 & 594.6 & 4.3 & 656.4 & 11.1 & 90.6 & 0.106 & $2.94 \mathrm{E}+15$ \\
\hline T95_15 & 95 & 1.114 & 1061 & 0.00 & 0.000 & 0.0611 & 0.0004 & 0.8274 & 0.0099 & 0.0982 & 0.0010 & 0.87 & 603.7 & 6.0 & 643.7 & 12.6 & 93.8 & 0.106 & $2.94 \mathrm{E}+15$ \\
\hline T95_16 & 22 & 0.012 & 263 & 0.00 & 0.001 & 0.0601 & 0.0004 & 0.7805 & 0.0104 & 0.0941 & 0.0011 & 0.86 & 579.9 & 6.4 & 608.6 & 14.5 & 95.3 & 0.023 & $6.47 \mathrm{E}+14$ \\
\hline T95_17 & 32 & 0.061 & 365 & 0.00 & 0.004 & 0.0600 & 0.0005 & 0.7885 & 0.0117 & 0.0953 & 0.0011 & 0.80 & 586.6 & 6.7 & 604.6 & 19.2 & 97.0 & 0.032 & $8.99 \mathrm{E}+14$ \\
\hline T95_18 & 171 & 1.650 & 1700 & 0.00 & 0.000 & 0.0612 & 0.0004 & 0.7918 & 0.0129 & 0.0938 & 0.0014 & 0.93 & 578.0 & 8.4 & 646.9 & 12.5 & 89.3 & 0.170 & $4.71 E+15$ \\
\hline T95_19 & 171 & 1.296 & 1441 & 0.00 & 0.000 & 0.0615 & 0.0004 & 0.8111 & 0.0115 & 0.0956 & 0.0012 & 0.90 & 588.7 & 7.2 & 657.5 & 13.3 & 89.5 & 0.144 & $3.99 E+15$ \\
\hline T95_20 & 114 & 0.234 & 1271 & 0.00 & 0.000 & 0.0611 & 0.0004 & 0.8292 & 0.0093 & 0.0984 & 0.0009 & 0.84 & 605.0 & 5.4 & 643.5 & 12.9 & 94.0 & 0.127 & $3.52 \mathrm{E}+15$ \\
\hline T95_21 & 17 & 0.075 & 118 & 0.00 & 0.000 & 0.0596 & 0.0003 & 0.7772 & 0.0095 & 0.0946 & 0.0011 & 0.92 & 582.7 & 6.2 & 588.7 & 10.3 & 99.0 & 0.010 & $2.91 \mathrm{E}+14$ \\
\hline T95_22 & 4 & 0.019 & 46 & 0.00 & 0.002 & 0.0601 & 0.0008 & 0.7844 & 0.0163 & 0.0947 & 0.0015 & 0.77 & 583.1 & 8.9 & 606.8 & 28.3 & 96.1 & 0.004 & $1.14 \mathrm{E}+14$ \\
\hline T95_23 & 5 & 0.042 & 59 & 0.00 & 0.002 & 0.0597 & 0.0006 & 0.7690 & 0.0138 & 0.0934 & 0.0013 & 0.80 & 575.4 & 7.9 & 594.1 & 23.0 & 96.8 & 0.005 & $1.45 \mathrm{E}+14$ \\
\hline T95_24 & 95 & 0.272 & 1101 & 0.00 & 0.000 & 0.0615 & 0.0003 & 0.8259 & 0.0106 & 0.0974 & 0.0012 & 0.92 & 599.1 & 6.8 & 656.8 & 10.6 & 91.2 & 0.110 & $3.05 E+15$ \\
\hline T95_25 & 97 & 1.008 & 1094 & 0.00 & 0.000 & 0.0614 & 0.0006 & 0.8022 & 0.0114 & 0.0948 & 0.0010 & 0.74 & 584.1 & 5.9 & 651.7 & 20.3 & 89.6 & 0.109 & $3.03 \mathrm{E}+15$ \\
\hline T95_26 & 101 & 0.949 & 1100 & 0.00 & 0.001 & 0.0614 & 0.0005 & 0.8310 & 0.0108 & 0.0982 & 0.0010 & 0.75 & 603.9 & 5.6 & 652.2 & 18.2 & 92.6 & 0.110 & $3.05 E+15$ \\
\hline T95_27 & 97 & 0.883 & 1083 & 0.00 & 0.000 & 0.0612 & 0.0006 & 0.8089 & 0.0106 & 0.0958 & 0.0009 & 0.73 & 589.8 & 5.4 & 647.5 & 19.3 & 91.1 & 0.108 & $3.00 \mathrm{E}+15$ \\
\hline T95_28 & 90 & 1.112 & 1018 & 0.00 & 0.001 & 0.0617 & 0.0006 & 0.8063 & 0.0117 & 0.0947 & 0.0011 & 0.78 & 583.4 & 6.4 & 665.2 & 19.2 & 87.7 & 0.102 & $2.82 \mathrm{E}+15$ \\
\hline T95_29 & 91 & 1.172 & 1009 & 0.00 & 0.001 & 0.0617 & 0.0006 & 0.8191 & 0.0126 & 0.0963 & 0.0011 & 0.75 & 592.6 & 6.5 & 663.5 & 21.7 & 89.3 & 0.101 & $2.80 \mathrm{E}+15$ \\
\hline T95_30 & 96 & 0.998 & 1053 & 0.00 & 0.000 & 0.0614 & 0.0005 & 0.8292 & 0.0128 & 0.0979 & 0.0012 & 0.82 & 601.9 & 7.3 & 655.0 & 18.7 & 91.9 & 0.105 & $2.92 \mathrm{E}+15$ \\
\hline T95_31 & 99 & 1.066 & 1109 & 0.00 & 0.000 & 0.0614 & 0.0005 & 0.8364 & 0.0110 & 0.0987 & 0.0010 & 0.74 & 606.9 & 5.6 & 654.8 & 18.9 & 92.7 & 0.111 & $3.07 \mathrm{E}+15$ \\
\hline T95_32 & 99 & 1.189 & 1101 & 0.00 & 0.000 & 0.0617 & 0.0005 & 0.8436 & 0.0102 & 0.0992 & 0.0009 & 0.73 & 609.5 & 5.1 & 663.7 & 17.7 & 91.8 & 0.110 & $3.05 E+15$ \\
\hline T95_33 & 95 & 1.180 & 1082 & 0.00 & 0.000 & 0.0615 & 0.0005 & 0.8206 & 0.0106 & 0.0968 & 0.0009 & 0.75 & 595.5 & 5.5 & 656.7 & 18.3 & 90.7 & 0.108 & $3.00 \mathrm{E}+15$ \\
\hline T95_34 & 82 & 1.092 & 936 & 0.00 & 0.000 & 0.0609 & 0.0005 & 0.8093 & 0.0106 & 0.0963 & 0.0009 & 0.75 & 592.7 & 5.6 & 637.3 & 18.3 & 93.0 & 0.094 & $2.59 \mathrm{E}+15$ \\
\hline
\end{tabular}




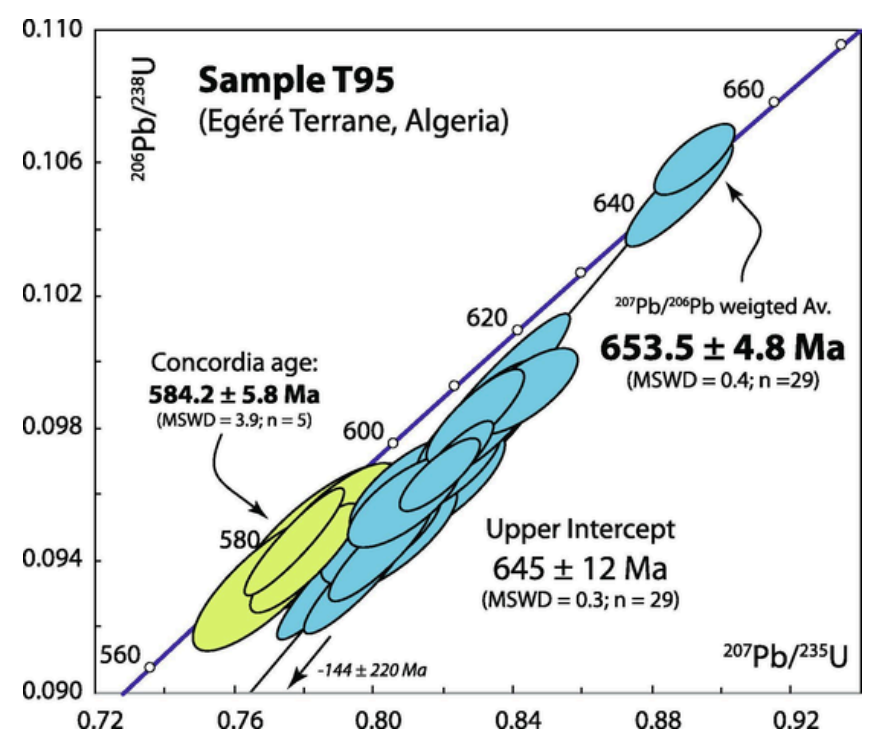

Fig. 5. Wetherill concordia plot of U-Pb zircon data. Error ellipses are $\pm 1 \sigma$ and ages are quoted at $\pm 2 \sigma$.

Table 4

Oxygen isotope analyses of the zircon megacryst from sample T95.

\begin{tabular}{llll}
\hline Sample & $16 \mathrm{O}\left(\mathrm{ps}\left(\mathrm{x} 10^{9}\right)\right.$ & $\mathrm{d}^{18} \mathrm{O}_{\text {SMOW }} \%$ & $\pm 1 \sigma$ \\
\hline T95@1_p1 & 2.81 & 7.12 & \\
T95@1_p2 & 2.84 & 9.09 & 0.13 \\
T95@1_p3 & 2.83 & 7.64 & 0.14 \\
T95@1_p4 & 2.85 & 10.39 & 0.13 \\
T95@1_p5 & 2.81 & 9.07 & 0.12 \\
T95@1_p6 & 2.91 & 9.73 & 0.13 \\
T95@2_p1 & 2.79 & 10.59 & 0.12 \\
T95@2_p2 & 2.83 & 10.57 & 0.13 \\
T95@2_p3 & 2.84 & 10.13 & 0.13 \\
T95@2_p4 & 2.90 & 9.93 & 0.13 \\
T95@2_p5 & 2.95 & 10.32 & 0.13 \\
T95@2_p6 & 2.94 & 9.91 & 0.13 \\
T95@2_p7 & 2.92 & 9.71 & 0.12 \\
T95@2_p8 & 2.96 & 9.49 & 0.13 \\
T95@2_p9 & 2.97 & 9.43 & 0.13 \\
T95@2_p10 & 2.97 & 8.88 & 0.13 \\
T95@3_p1 & 2.77 & 11.47 & 0.13 \\
T95@3_p2 & 2.65 & 11.15 & 0.13 \\
T95@3_p3 & 2.74 & 10.20 & 0.13 \\
T95@3_p4 & 2.83 & 11.27 & 0.12 \\
T95@3_p5 & 2.87 & 10.03 & 0.13 \\
T95@4_p1 & 2.83 & 10.47 & 0.13 \\
T95@4_p2 & 2.83 & 11.07 & 0.12 \\
T95@4_p3 & 2.86 & 10.11 & 0.13 \\
T95@4_p4 & 2.84 & 10.02 & 0.13 \\
T95@4_p5 & 2.91 & 9.75 & 0.13 \\
T95@5_p1 & 2.71 & 10.24 & 0.12 \\
T95@5_p2 & 2.44 & 12.34 & 0.13 \\
T95@5_p3 & 2.61 & 10.93 & 0.13 \\
T95@5_p4 & 2.64 & 10.20 & \\
T95@5_p5 & 2.76 & & \\
\hline & & & \\
& & & \\
\hline
\end{tabular}

left to right. This is particularly clear on profile @2, which yields a steady rightward decrease of $\delta^{18} \mathrm{O}$ values from $10.6 \%$ to $8.9 \%$. Overall, the heavy $\delta^{18} \mathrm{O}$ values are consistent with surface alteration of the protolith(s) by liquid water at low temperature. Anatexis of this protolith provided a melt with a high $\delta^{18} \mathrm{O}$ from which the megacryst crystallized and inherited the heavy oxygen signature.

Hf isotopes were measured at ten locations (see Fig. 3D). Initial $\mathrm{Hf}$ isotope ratios were calculated using the $\mathrm{U}-\mathrm{Pb}$ age of the megacryst (650 Ma) and are reported in Table 5. Analyses conducted at different places of the megacryst yield a limited range of ${ }^{176} \mathrm{Hf} /{ }^{177} \mathrm{Hf}$ of $0.281761-0.281844$ and $\varepsilon \mathrm{Hf}(\mathrm{t})_{\mathrm{CHUR}}$ of -19.7 to -22.5 , with a mean of $-20.7 \pm 1.0$. It is noteworthy that although $\mathrm{Hf}$ analyses were conducted at different locations, in particular in the high $\mathrm{U}$ domain (\#5 and \#6), or in the fractured rim (\#9 and \#10) in the left upper part of the crystal or close to the edge (\#4 and \#8), the Hf isotopic values are not significantly different. This contrasts with the large variations observed for the oxygen isotopes and suggests that the Lu-Hf system remained little/ not disturbed in the whole crystal. The negative $\mathrm{EHf}_{\mathrm{t}}$ values indicate that pre-existing continental crust (or material derived from it) was involved in melt genesis from which the zircon crystallized. The $\mathrm{Hf}_{\mathrm{DM}}$ model ages range from 2805 to $2983 \mathrm{Ma}$, which indicates reworking of Archean material in the production of the melt.

\subsection{Trace elements in rutile}

Analyzed rutile occurs as matrix grains in the thin section. The analyzed grains display a very low $\mathrm{Cr}$ content $(<100 \mathrm{ppm})$ but a high $\mathrm{Nb}$ content ranging from 2898 to $7038 \mathrm{ppm}$ (see Table 1). In the dichotomic Cr-Nb diagram of Triebold et al., 2012, the four analyses plot in the field of rutile from metapelitic protolith (Fig. 6), which is consistent with production of the leucosome by melting of pelitic material as deduced from $\mathrm{Hf}$ and $\mathrm{O}$ isotopes in the zircon megacryst. The analyzed grains show sub-chondritic $\mathrm{Zr} / \mathrm{Hf}$ ratios (16.5-22.9), but supra-chondritic and highly variable $\mathrm{Nb} / \mathrm{Ta}$ ratios (25.2-79.5). Their Zr content ranges from 493 to 739 ppm, which, using the thermometer of Ferry and Watson (2007), results in a mean temperature of $702 \pm 24{ }^{\circ} \mathrm{C}$ (assuming a $\pm 25^{\circ} \mathrm{C}$ uncertainty for each measurement). This is significantly lower than the Ti-in-zircon temperature calculated for the central part of the megacryst $\left(811 \pm 15^{\circ} \mathrm{C}\right)$, but it is in good agreement with the temperature calculated from its border $\left(717 \pm 25^{\circ} \mathrm{C}\right)$.

\section{Discussion}

Thanks to its millimetric size, the zircon megacryst discovered in the thin section allowed performing a large range of chemical and isotopic analyses, which together provide a unique opportunity to pinpoint its age and crystallization environment as well as the post-crystallization events registered by the different chemical systems. When combined with the P-T information available for the surrounding basement rocks of the Egéré terrane, this also enables to link the chemical record of the zircon with known geological events. More specifically, the new data have important implications for the geodynamic evolution of the Egéré terrane during the Neoproterozoic amalgamation of the Tuareg Shield.

\subsection{Origin of the megacryst: detrital grain inherited from the surrounding metapelites or in situ crystallization from the anatectic melt?}

Clarification of the origin of the zircon megacryst is key to the interpretation of the geochemical data, especially when it comes to building a large-scale geodynamic model of evolution for the Egéré terrane and the Tuareg Shield. The zircon megacryst can indeed be regarded either as crystallized from the anatectic melt producing the pegmatitic leucosome, or as being inherited, i.e. transported from source or surrounding rocks by the anatectic melt from which the pegmatite crystallized. The question is worth asking since the leuco- 
Table 5

Hf isotope analyses of the zircon megacryst from sample T95.

\begin{tabular}{|c|c|c|c|c|c|c|c|c|}
\hline Sample & $176 \mathrm{Yb} / 177 \mathrm{Hf}$ & 176Lu/177Hf & 176Hf/177Hf* & $\pm 2 \sigma$ & $176 \mathrm{Hf} / 177 \mathrm{Hf}^{* * *}$ & $\varepsilon \mathrm{Hf}_{\mathrm{i}}$ & $\pm 2 \sigma$ & $\mathrm{T}_{\mathrm{DM}}$ \\
\hline T95_\#01 & 0.0661 & 0.0019 & 0.28184 & 0.00001 & 0.28181 & -19.5 & 0.7 & 2817 \\
\hline T95_\#02 & 0.0649 & 0.0018 & 0.28184 & 0.00001 & 0.28181 & -19.6 & 0.7 & 2822 \\
\hline T95_\#03 & 0.0694 & 0.0020 & 0.28184 & 0.00001 & 0.28182 & -19.4 & 0.7 & 2807 \\
\hline T95_\#04 & 0.0645 & 0.0018 & 0.28183 & 0.00001 & 0.28181 & -19.9 & 0.6 & 2838 \\
\hline T95_\#05 & 0.1080 & 0.0030 & 0.28178 & 0.00001 & 0.28174 & -22.2 & 0.7 & 2985 \\
\hline T95_\#06 & 0.0350 & 0.0008 & 0.28179 & 0.00001 & 0.28178 & -20.8 & 0.6 & 2898 \\
\hline T95_\#07 & 0.0752 & 0.0021 & 0.28180 & 0.00001 & 0.28178 & -20.9 & 0.7 & 2899 \\
\hline T95_\#08 & 0.0720 & 0.0021 & 0.28183 & 0.00001 & 0.28181 & -19.8 & 0.7 & 2835 \\
\hline T95_\#09 & 0.0106 & 0.0003 & 0.28181 & 0.00001 & 0.28180 & -19.9 & 0.8 & 2841 \\
\hline T95_\#10 & 0.0108 & 0.0003 & 0.28176 & 0.00001 & 0.28176 & -21.6 & 0.8 & 2944 \\
\hline \multicolumn{5}{|c|}{ Weighted mean: } & 0.28179 & -20.4 & 1.0 & 2869 \\
\hline
\end{tabular}

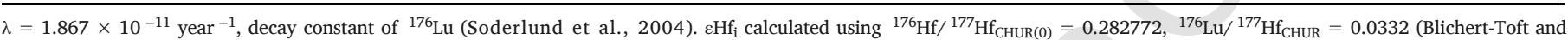
Albarède, 1997).

* Measured ratios, ** Age corrected ratios.

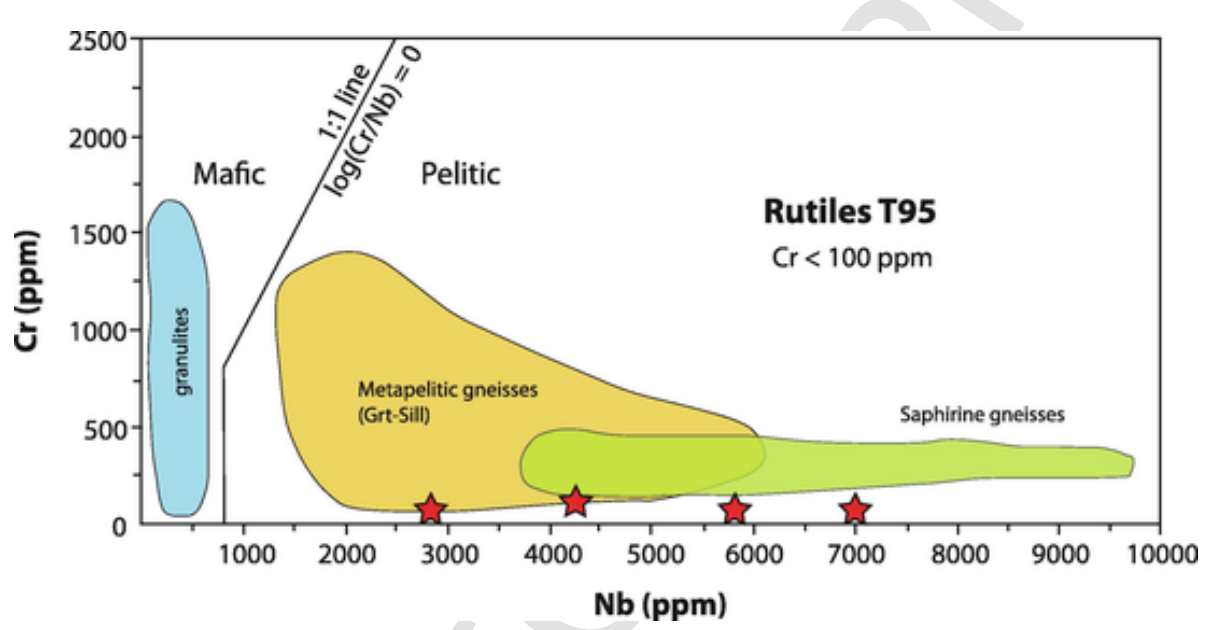

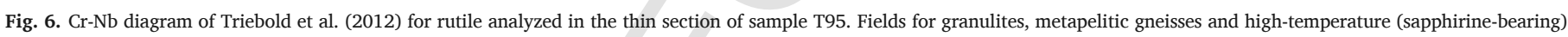
gneisses are from Meyer et al. (2011).

some was sampled within anatectic metapelites, a material that commonly hosts large amounts of zircon and from which the megacryst may well be inherited. In the following we argue that the megacryst crystallized from the melt producing the leucosome and is not a relict mineral preserved from the metapelite. First, surrounding metapelites are fine-grained sediments for which the particle size (typically less than $63 \mu \mathrm{m}$ ) is not compatible with that of the zircon megacryst. Second, minerals in the leucosome that are clearly related to crystallization from the melt (K-feldspar, white mica, quartz) are coarse grained and are consistent with the size of the megacryst. As already mentioned, the ragged appearance of the edge of the crystal, especially in its lower part, indicates a modification of the original shape due to dissolution processes. This could be taken as evidence for magmatic corrosion during residence of the megacryst in a melt, thus lending support to the inheritance hypothesis. However, a close examination of the crystal shows that this ragged appearance is always associated with the feldspathic band surrounding almost entirely the crystal and cutting across both the zircon and the large K-feldspar engulfing the latter. Where this band is absent, the contact between the zircon and the K-feldspar is sharp and does not show any sign of corrosion. Thus, we argue that the ragged appearance visible in some parts of the grain is due to late alteration by fluids, and not to residence of a crystal inherited from the surrounding metapelites in a zirconium undersaturated melt. Another independent argument for crystallization of the megacryst from the leucosome is provided by the study of Arab (2016), in which U-Pb ages were measured on detrital zircon grains $(n=120)$ from the surrounding metapelites. The cores of these zircons define an age spectrum ranging 745-3094 Ma, with no detrital age younger than $745 \mathrm{Ma}$ detected. Conversely, the low $\mathrm{Th} / \mathrm{U}$ rims of these zircons define an age of $648 \pm 10 \mathrm{Ma}$ (Arab, 2016), which was attributed to a metamorphic growth event. We therefore consider that derivation of the megacryst from the surrounding metapelite as an inherited grain is unlikely, and favor the interpretation that the zircon crystallized from the anatectic melt corresponding to the pegmatitic leucosome. The U-Pb age of $654 \pm 5$ Ma obtained in this study is thus taken as our best estimate for partial melting of the metapelite and production of the pegmatitic leucosome. The younger age of $c$. 580 Ma obtained on some domains of the crystal is related to post-crystallization disturbances, the significance of which is discussed below.

\subsection{Signature, stability and behaviour of chemical and isotopic tracers}

From the arguments above, the megacryst is interpreted as having crystallized from the anatectic melt that produced the pegmatitic leucosome and is thus of magmatic origin. The euhedral to subhedral shape of the grain is consistent with this view as well as the growth bands observed in natural light that correspond to oscillatory zoning, a common feature of magmatically grown zircon (e.g., Hoskin and Schaltegger, 2003). The REE pattern of the central part is also typical of magmatic zircon (e.g., Barth et al., 2016), with steep HREE 
pattern $\left(\mathrm{Gd} / \mathrm{Yb}_{\mathrm{N}}>30\right)$ and a prominent positive Ce anomaly. The megacryst displays a very low $\mathrm{Th} / \mathrm{U}$ ratio (mean value of 0.0009 for the 29 analyses used in the age calculation), largely less than 0.1 , a threshold below which zircon is classically considered as solid state grown (e.g., Williams and Claesson, 1987; Rubatto, 2002; Gilotti et al., 2014) but that has also been attributed to suprasolidus metamorphic zircons crystallized from a melt. In anatectic melts, the Th/ $\mathrm{U}$ of zircon can reflect element availability (Th/ $\mathrm{U}$ ratio and $\mathrm{U}$ and $\mathrm{Th}$ concentration of the melt source) or buffering of the crystallizing environment by mineralogical phases partitioning Th against $\mathrm{U}$, such as allanite, apatite and monazite (e.g., Rubatto et al., 2009; Yakymchuk et al., 2018). In the studied rock, we found no candidate minerals that can strongly partition Th against $\mathrm{U}$ to impose a low $\mathrm{Th} / \mathrm{U}$ ratio to the zircon, in particular no monazite was observed in the thin section. It is thus likely that the low $\mathrm{Th} / \mathrm{U}$ ratio of the megacryst reflects the Th/U ratio of the anatectic melt from which the zircon crystallized, hence suggesting sequestration of Th in the residual assemblage. This conclusion is supported by modelling of melting in metapelitic systems (e.g., Hermann and Rubatto, 2009), which indicates that at c. $800{ }^{\circ} \mathrm{C}$ and $25 \mathrm{kbar}$ residual allanite, and at higher pressure residual monazite, is expected to coexist with melts, with up to $c$. $50 \%$ partial melting. The zircon megacryst-bearing leucosome can thus be interpreted as an allanite/monazite buffered melt.

Trace element composition of the edge of the crystal indicates that the pattern of magmatic zircon observed in the inner part of the megacryst has been deeply modified. This is evident from the three analyses carried out close to the upper and lower terminations. In these three analyses, the HREE content is significantly lower. In addition, the analysis with the least pronounced positive Ce anomaly displays the highest LREE content. The low HREE content is not related to modification of the essential structural element such as $\mathrm{Si}$ or $\mathrm{Zr}$ since EPMA analyses do not show any significant differences (see Table 1). Thus, lowering of the HREE is real and is not a side effect of an incorrect internal standardization. These altered domains are also characterized by a lowering of HFS, fluid immobile, elements ( $\mathrm{Nb}$ and $\mathrm{Ta}$ ) and a drastic loss of $\mathrm{Y}$ (divided by four on average) and $\mathrm{U}$ (broadly divided by three). These variations in element contents are not accompanied by significant variations in invariant inter-element ratios such as $\mathrm{Nb} / \mathrm{Ta}$ or $\mathrm{Y} / \mathrm{Ho}$ (see Table 2), indicating that no fractionation had occurred. Purging of elements has been proposed by Pidgeon (1992) as typical of solid-state recrystallisation processes and is in agreement with the observed variations. The Hf isotopic composition measured throughout the whole crystal does not show significant variations and provides consistently negative $\varepsilon \mathrm{Hf}_{\mathrm{i}}$ (mean $\varepsilon \mathrm{Hf}_{\mathrm{i}}=-20.7 \pm 1.0$ ), including two analyses from the edge of the crystal (see Table 3). This observation further supports recrystallisation processes rather than new zircon growth. These recrystallization processes were efficient in modifying the chemical composition of parts of the megacryst, particularly in lowering most trace elements (U, Nb, Ta, Y and $\Sigma$ REE), but did not affected the composition of the major elements ( $\mathrm{Si}, \mathrm{Zr}$ and $\mathrm{Hf}$ ) constituting the crystal lattice. It is therefore not surprising that the Hf isotopic composition remained unaffected by these processes, and this in turn emphasizes further the robustness of the Lu-Hf isotopic system within the zircon.

The behavior of oxygen isotopes is puzzling. The large variations of $\delta^{18} \mathrm{O}$ observed throughout the megacryst, from $7.1 \%$ o to $12.3 \%$, clearly call for an isotope heterogeneity. Because the megacryst has a high mean $U$ content of $c$. $1000 \mathrm{ppm}$ on average, we first compare the $\mathrm{U}$ content with the $\delta^{18} \mathrm{O}$ values measured. Indeed, recent studies have highlighted the correlation between the metamictisation state of the crystals and a lowering of the oxygen isotope composition (e.g., Gao et al., 2014a, 2014b). Similarly, fluid circulation along cracks and interaction with radiation-damaged zircon domains can also be envisioned (e.g., Pidgeon et al., 2017). The U content in zircon can be used as a proxy for the degree of radiation damage to the crystal. However, following Meldrum et al. (1998) we consider that the dose in displacement per atom $\left(\mathrm{D}_{\mathrm{dpa}}\right)$ constitutes a more efficient proxy, because this approach also takes the age, and thus the accumulated radiation damages, into account. In the megacryst, the average degree of radiation damage as measured by the $\alpha$ dose is around $0.11 \mathrm{D}_{\mathrm{dpa}}$ (or $2.94 \times 10^{15} \alpha / \mathrm{mg}$ ) for the analyses quoted in Table 3 . This is close to, although slightly below, the first stage of damage accumulation in zircon. This stage is dominated by the formation of isolated point defects (Murakami et al., 1991), which anneal over time under low temperature conditions. This degree of $\alpha$ dose can explain the slight, zero age, discordance (and loss of radiogenic $\mathrm{Pb}$ ) of the analyzed zircon domains, but also indicates that most of the megacryst was not deeply modified by radiation damages. In addition, analyses performed in the high $\mathrm{U}$ zone (left upper part) of the megacryst display $\delta^{18} \mathrm{O}$ values of $10.2-10.9$ (see Table 4) which are not significantly different from lower U domains, although the calculated $\alpha$ dose of $0.50 \mathrm{D}_{\mathrm{dpa}}\left(1.4 \times 10^{16} \alpha / \mathrm{mg}\right)$ is typical of aperiodic zircon domains (Murakami et al., 1991). It follows that variations of the oxygen isotopes within the megacryst are not related to the degree of radiation damage to the zircon lattice nor to fluid circulation along cracks allowing reaction with damaged zircon domains. Then what is the cause for such large oxygen isotope variations? Profile @1 set apart, oxygen isotope compositions show a tendency to become progressively lighter rightwards. This is particularly obvious for the longest profile @2, with values decreasing from 10.6 to $8.9 \%$. Again, this trend to lighter oxygen values is not correlated with the $\mathrm{D}_{\mathrm{dpa}}$. Experimental or natural examples indicate low diffusivity of $\mathrm{O}$ and preservation of the original oxygen isotopic signature in zircon up to high temperatures corresponding to granulite facies conditions (e.g., Watson and Cherniak, 1997; Peck et al., 2003), thus also precluding volume diffusion as a viable mechanism to explain the unidirectional large isotopic variations in the megacryst. Oxygen isotope zoning has been observed in large garnet grains and zircon (e.g., Chamberlain and Conrad, 1991; Page et al., 2019), where sharp core to rim variations have been attributed to changes in the isotopic composition of the metamorphic fluids with which the crystals equilibrated. The smooth unidirectional trend observed in the megacryst is however not consistent with such zoning. It is generally agreed that under wet conditions, the retentivity of the primary $\mathrm{O}$ signature in various minerals, including zircon, is much less robust (Watson and Cherniak, 1997) and that isotopic exchanges at lower temperatures can be promoted by interactions with fluids with the likelihood of a partial isotopic re-equilibration (e.g., Martin et al., 2008). In the megacryst, the large variations observed, and the rightward trend toward lighter oxygen signatures suggest isotopic exchanges and partial resetting. This is consistent with the lighter oxygen isotopic composition observed in the lower part of the grain (down to $7.6-7.1 \%$ o). These values have been measured close to the feldspathic veinlet in contact with the megacryst. Interaction between this veinlet and the megacryst is evidenced by the saw-tooth shape of the edge of the grain (see Figs. 2 and 3). We thus speculate that the variations in the oxygen isotopic signatures result from alteration of the host rock driven by interaction with a low $\delta^{18} \mathrm{O}(\leq 7.1 \%$ ) fluid. It is noteworthy, that the $\delta^{18} \mathrm{O}$ measured in the lower edge of the grain are heterogeneous (see profile @1 with $\delta^{18} \mathrm{O}$ ranging from 7.1 to $10.4 \%$ ) indicating that fluid-mineral interaction was not efficient, on a large-scale, to fully reset the $\mathrm{O}$ isotopes. In addition, we argue that the rightward trend observed in profile @ 2 is consistent with a gradient tied to the occurrence of the large K-feldspar on the left of the megacryst which protected the zircon grain from percolating fluids and provided a shielding effect. 
This study thus constitutes an example of a zircon grain with a magmatic internal structure (oscillatory zoning) that, in most parts, preserved its primary trace-element (REE, Ti) and isotopic (Hf and $\mathrm{U}-\mathrm{Pb}$ ) signatures. Only in recrystallized domains, the trace elements and U-Pb systems were deeply modified by purging of elements and resetting of the U-Pb chronometer. Conversely, the $\mathrm{O}$ isotope signature was pervasively modified but not fully re-equilibrated during subsolidus secondary exchanges with a fluid phase. The complete resetting of the $\mathrm{O}$ isotope signature was probably hampered by the huge size of the megacryst slowing diffusion. A major conclusion is thus that, under equivalent conditions, the retentivity of zircon for $\mathrm{O}$ is lower than for REE, HFSE (Hf and Ti notably) and $\mathrm{Pb}$. In addition, in usual cases were zircon size is typically in the range $80-150 \mu \mathrm{m}$, a complete and eventually unrecognized modification of the $\mathrm{O}$ signature can occur, with the risk of linking secondary $\mathrm{O}$ signature to primary trace elements, $\mathrm{Hf}$ and $\mathrm{U}-\mathrm{Pb}$ characteristics. Concerning the studied megacryst, deciphering its primary $\mathrm{O}$ signature is difficult but we posit that the highest $\delta^{18} \mathrm{O}$ measured (from 11.2 to $12.3 \%$ ) plead for a metasedimentary source for the melt, in agreement with the Hf isotopes which indicate recycling of an Archean crustal component (average $\mathrm{Hf} \mathrm{T}_{\mathrm{DM}}$ of $c .2 .8 \mathrm{Ga}$ ) and with the intrusive nature of the leucosome in the surrounding metapelites.

\subsection{Geodynamic implications}

Recent studies by Doukkari et al. (2014) and Doukkari et al. (2015) identified three major metamorphic evolutionary stages on eclogites from the Tighsi area in the Egéré-Aleksod terrane. Garnet cores in eclogite emphasize peak metamorphic conditions at $19.6 \mathrm{kbar}$ and $694{ }^{\circ} \mathrm{C}$ (M1), followed by heating to $774{ }^{\circ} \mathrm{C}$ during decompression at $15.5 \mathrm{kbar}$ (M2) and retrograde exhumation at $9.3 \mathrm{kbar}$ and $695{ }^{\circ} \mathrm{C}$ (M3). In the studied anatectic leucosome, the megacryst crystallized at $654 \pm 5 \mathrm{Ma}$ at a temperature of $811 \pm 15{ }^{\circ} \mathrm{C}$ (see Fig. 7). This temperature is slightly higher than, but probably within errors of, the temperature attributed to the M2 event of Doukkari et al. (2014). Post-peak heating during exhumation is typical of HP rocks involved in collisional orogen and is often accompanied by partial melting of felsic and metasedimentary rocks surrounding eclogites (e.g., Gao et al., 2011). This is also consistent with experimental studies (e.g., Vielzeuf and Holloway, 1988; Auzanneau et al., 2006), indicating that partial melting of metapelitic rocks and metagraywackes initiates between 800 and $900{ }^{\circ} \mathrm{C}$ during decompression. We thus propose that production of the anatectic leucosome was accomplished during M2. It follows that the peak of HP eclogitic metamorphism in the Tighsi area (c. 20 kbar after Doukkari et al., 2014, 2015) of the Egéré terrane is older than $654 \pm 5$ Ma.

This minimum age for the eclogite facies metamorphism is significantly younger than the $685 \pm 19 \mathrm{Ma} \mathrm{Sm} / \mathrm{Nd}$ mineral isochron age of garnet amphibolites in the Laouni terrane, further south (Liégeois et al., 2003). We first note that the latter age has been interpreted as dating the retrograde amphibolite facies metamorphism $\left(12 \mathrm{kbar}-830{ }^{\circ} \mathrm{C}\right)$ and is thus also a minimum age for the climax of eclogite facies conditions in LATEA. In addition, the P-T conditions for amphibolite facies metamorphism in Laouni are shallower (12 kbar versus $15.5 \mathrm{kbar}$ ) and hotter $\left(830^{\circ} \mathrm{C}\right.$ versus $774{ }^{\circ} \mathrm{C}$ ) suggesting that both environments may not be fully comparable. Assuming that all eclogite occurrences in LATEA once belonged to a single unit of $c$. $500 \mathrm{~km}$ long, as proposed by Liégeois et al. (2003), the differences in P-T conditions and age of retrograde metamorphism between the Egéré and Laouni terranes may be related to different burial and exhumation kinetic along strike. Although this needs further substantiation, these differences could also indicate a N-S diachronism of HP metamorphism, with eclogite facies conditions and onset of exhumation reached earlier southward. This diachronism may be related to the geometry of the initial contact between the Iskel terrane and LATEA which could have been non-linear and for example inherited from the rifting phase affecting LATEA and that subsequently evolved to an oceanic domain (the so called Ammas ocean of Liégeois, 2019).

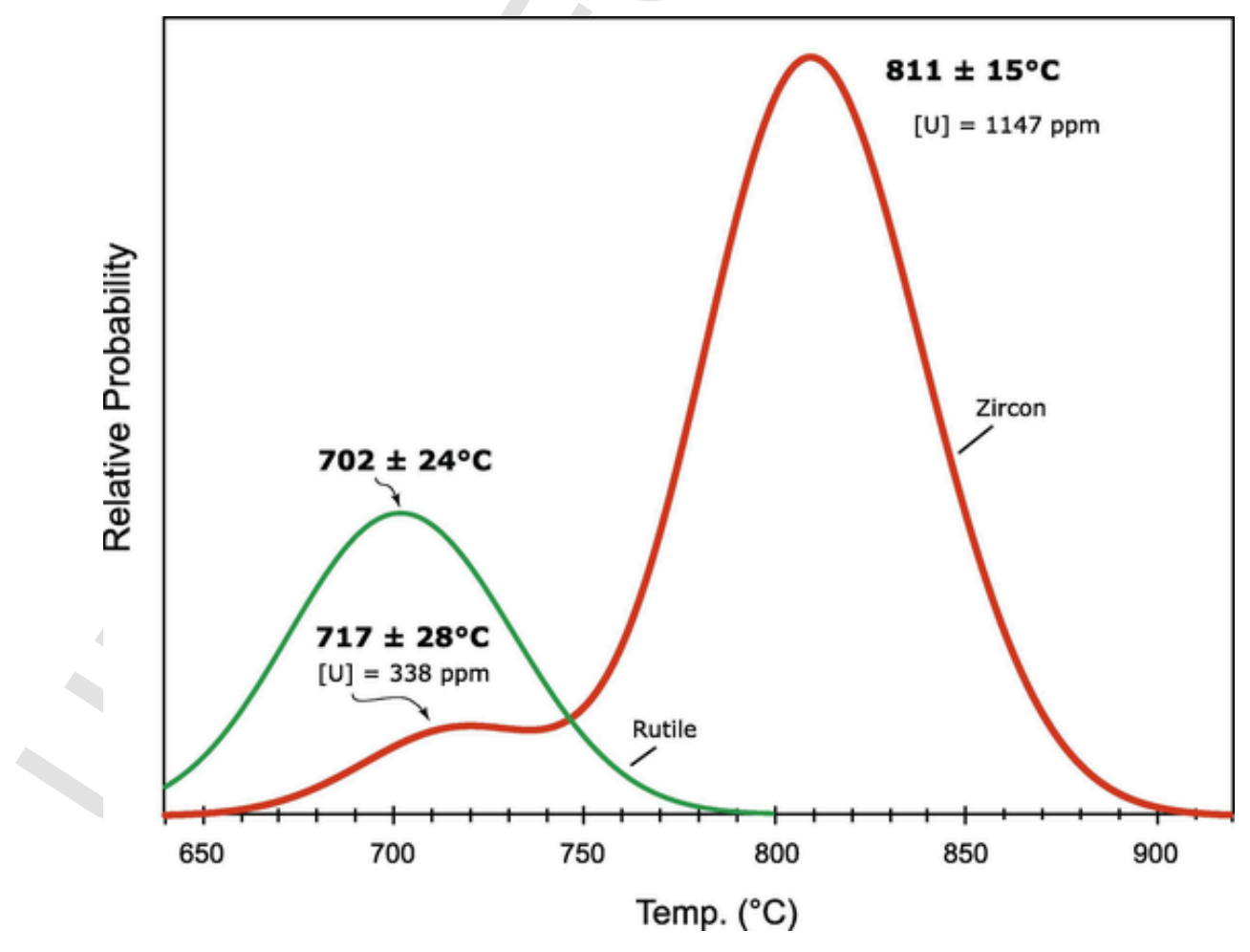

Fig. 7. Histogram of temperatures recorded for the zircon megacryst (central part and rim) and rutile grains in sample T95. 
Another interesting point to discuss is the comparison with HP metamorphism that developed along the western part of the Tuareg Shield (i.e. Tassendjanet terrane, Caby and Monié, 2003; Berger et al., 2014), along the WAC (Gourma and Togo, Jahn et al., 2001; Ganade de Araujo et al., 2014) and in Brazil (Forquilha, Ganade de Araujo et al., 2014). In this part of the orogen, subduction and formation of oceanic island-arc is older than c. 750-800 Ma owing to the age of well-preserved intra-oceanic island arcs (El Hadi, 2010; Berger et al., 2011; Bosch et al., 2016). This is comparable to the age of the oldest calc-alkaline magmatism (870-840 Ma) in the Iskel terrane (Caby et al, 1982), west of LATEA, and attributed to the westward subduction of the Ammas Ocean. This indicates that subduction of oceanic domains on both sides of Western Hoggar was mainly coeval (>800 Ma). The main difference resides in the age of HP eclogite facies metamorphism. In the western part of the Tuareg Shield, HP metamorphism and fast exhumation to lower crustal levels occurred in the restricted time range of 610-625 Ma, just after the beginning of the Tuareg/WAC collision (c. $630 \mathrm{Ma}$ after Caby, 2003). This is significantly younger than the $\geq 650 \mathrm{Ma}$ age constraints for eclogite facies metamorphism and onset of exhumation in the Egéré (this study) and Laouni terranes (Liégeois et al., 2003). Since exhumation of HP rocks most often occurs during the first stages of collision, we conclude that closure of oceanic domains and collision stages were clearly diachronous in the Tuareg Shield. In the central part of the Tuareg Shield, west of LATEA, consumption of the Ammas ocean started at c. $870 \mathrm{Ma}$ (Caby et al., 1982) and lasted until 650-640 Ma (Bechiri-Benmerzoug et al., 2011), the age of the youngest calc-alkaline batholiths in the Iskel island-arc terrane. The age of these youngest plutons is broadly consistent with the onset of exhumation of HP units in the Egéré terrane, suggesting cause and effect relationships. We suggest that this period reflects the end of subduction processes and the collision with the passive margin of LATEA. Shallow underthrusting of the lithosphere of LATEA beneath Iskel may have triggered exhumation of subducted units when slab pull was counterbalanced by buoyancy of continental units entering subduction.

Recrystallization of the edge of the zircon megacryst occurred at $584 \pm 6 \mathrm{Ma}$ at a temperature of $717^{\circ} \mathrm{C}$, which is the same as that recorded by matrix rutile $\left(702 \pm 24{ }^{\circ} \mathrm{C}\right)$ (Fig. 7). Gao et al. (2014b), and later Sengun and Zack (2016), first proposed to tie the $\mathrm{Nb} / \mathrm{Ta}$ ratio of rutile to its prograde or retrograde growth, where supra-chondritic values (>17.6 after McDonough and Sun, 1995) reflect a retrograde growth event. Rutile analyzed in this study displays a wide range of supra-chondritic $\mathrm{Nb} / \mathrm{Ta}$ ratios ranging from 25.2 to 79.5 and we thus conclude that its growth occurred in the retrograde path. On that ground, it is tempting to link rutile growth and zircon recrystallization to the retrograde stage of metamorphism, in particular to M3 that is characterized by P-T conditions of $9.3 \mathrm{kbar}$ and $695{ }^{\circ} \mathrm{C}$ (Doukkari et al., 2014). In such a case, the $584 \pm 6$ Ma recrystallization age of parts of the megacryst would then provide our best estimate for the retrograde stage M3. Combining this constraint with the age of $654 \mathrm{Ma}$ for production of the anatectic leucosome during M2 (15.5 kbar and $774{ }^{\circ} \mathrm{C}$ ), we calculate a mean cooling and exhumation rate of $1.1{ }^{\circ} \mathrm{C}$ / Myr and $0.26 \mathrm{~km} / \mathrm{Myr}$. These very low rates contrast with regurgitation of (U)HP buoyant crustal slices which typically rise to mid-crustal levels at exhumation rates of c. $10 \mathrm{~km} / \mathrm{Myr}$ (e.g., Ernst, 2001). Most importantly such a calculation implies that LATEA went through a steady cooling in the 650-580 Ma time range. This is clearly not realistic since the 615-580 Ma time range corresponds to the climax of intrusion of large batholiths in LATEA (Bertrand et al., 1986) inducing recrystallisation of zircon in Paleoproterozoic basement gneisses (e.g., Barbey et al., 1989; Bendaoud et al., 2008) and followed by emplacement of shallow circular plutons (e.g., Abdallah et al., 2007).
We thus contend that recrystallisation of the zircon megacryst at $c$. $580 \mathrm{Ma}$ cannot be used to extrapolate the cooling path followed by basement rocks in LATEA since this age is likely to reflect reheating of the lower/middle crust. The observation by Caby and Bruguier (2018) that large parts of the Arechchoum gneisses include diatexites and consist of anatectic elongated domes displaying features of hot orogens submitted to viscous flow (e.g., Rey et al., 2011) strongly supports the occurrence of a partially molten crustal level in the lower crust of LATEA at that time. This soft crustal level may have assisted escape tectonics along major lithospheric shear zones such as the $400 \mathrm{~B} 050^{\prime}$ or $8^{\circ} 30^{\prime}$ occurring at the end of the Pan-African orogeny.

In addition, in the eastern part of the Tuareg Shield, east of the $8^{\circ} 30^{\prime}$ shear zone, the period between 575 and 555 Ma was characterized by an intracontinental deformation (Fezaa et al., 2010) related to the Murzuk craton, a rigid and undeformed part of the composite Saharan metacraton (Abdelsalam et al., 2002; Liégeois et al., 2013). This activity corresponds to the end of the Pan-African events in the Central and Eastern part of the Tuareg Shield and most likely to reorganization of plate boundaries during consumption of the last remaining (weak) spaces. We propose that the final push of the Saharan metacraton in the East was responsible for the observed architecture of the Egéré terrane (Caby and Bruguier, 2018), where elongated domes of basement gneisses alternate with HP metasedimentary synforms of the Egéré group.

\section{Conclusion}

By combining geochemical (major and trace elements, $\mathrm{O}$ and Hf isotopes) and geochronological data on a zircon megacryst from a leucosome intruding HP metapelites from the Egéré group, we show that the megacryst has typical igneous characteristics and crystallised at $654 \pm 5 \mathrm{Ma}$ at a temperature of $c .800{ }^{\circ} \mathrm{C}$ from a melt produced in the stability field of monazite. Oxygen and $\mathrm{Hf}$ isotopes substantiate production of the anatectic melt by partial melting of metasedimentary sources, which are likely to be the surrounding metapelites. Saw-tooth edge of the megacryst at the contact with feldspathic veinlets indicates fluid-mineral interactions, which triggered recrystallisation of parts of the megacryst at $584 \pm 6 \mathrm{Ma}$ and $c .700{ }^{\circ} \mathrm{C}$. Recrystallisation did not affect the Hf isotope signatures but was responsible for lowering of some trace element contents (including HFSE, U and Y). In addition, we show that this event was responsible for a pervasive disturbance of $\mathrm{O}$ isotopes in the megacryst. This is consistent with experimental data showing that the retentivity of $\mathrm{O}$ isotopic signatures in zircon under wet conditions is lower (Watson and Cherniak, 1997).

Using these data and published petrological ones (Doukkari et al., 2014), we propose that the HP metasediments of the Egeré group, which were buried to depth of c. $20 \mathrm{kbar}\left(700^{\circ} \mathrm{C}\right)$, started their post-peak exhumation by decompression heating (c. 16 kbar and $800{ }^{\circ} \mathrm{C}$ ) at $654 \pm 5 \mathrm{Ma}$. This evolution contrasts with the younger metamorphic evolution for HP units preserved along the western part of the Tuareg Shield (peak HP and exhumation occurring between 625 and $610 \mathrm{Ma}$; e.g., Jahn et al., 2001; Berger et al., 2014; Ganade de Araujo et al., 2014). Although subduction of oceanic domains was broadly coeval on both sides of Western Hoggar, this indicates that HP metamorphism and collision stages were diachronous.

Fluid-mediated recrystallization of zircon domains at $584 \pm 6 \mathrm{Ma}$ is coeval with the climax of batholith intrusion in LATEA. This observation, and the anatectic nature of large parts of basement rocks in the Egéré terrane, suggests the existence of a partially molten crustal level in LATEA, which could have assisted the tectonic escape of crustal blocks along major lithospheric shear zones at the end of the Pan-African orogeny. 
"Old zircons never die" but time leaves indelible scars on their geochemical DNA that are testimony of the diversity of events they went through. This can be seen as a blessing rather than a curse providing high spatial resolution and high precision analyses can be performed in order to unravel and pinpoint the vast information recorded in tiny intra-crystalline domains of single zircon crystals as well as other accessories (e.g., Fisher et al., 2020).

\section{Uncited reference}

Zheng et al. (2011).

\section{CRediT authorship contribution statement}

O. Bruguier: Conceptualization, Investigation, Methodology, Writing - original draft, Writing - review \& editing. R. Caby: Conceptualization, Investigation, Writing - original draft, Writing - review \& editing. D. Bosch: Conceptualization, Methodology, Writing - original draft, Writing - review \& editing. K. Ouzegane: Conceptualization, Investigation, Writing - original draft. E. Deloule: Conceptualization, Methodology, Writing - original draft. B. Dhuime: Conceptualization, Methodology, Writing - original draft. A. Bendaoud: Conceptualization, Investigation, Writing - original draft. J.R. Kienast: Conceptualization, Investigation, Writing - original draft.

\section{Declaration of Competing Interest}

The authors declare that they have no known competing financial interests or personal relationships that could have appeared to influence the work reported in this paper.

\section{Acknowledgments}

The authors are grateful to C. Nevado and D. Delmas for performing the thin sections, to F. Fernandez for SEM analyses and to B. Boyer for EPMA guidance. O.B. acknowledges funding from the TelluS Syster program of the CNRS-INSU (Project Call - AO2016). Special thanks to Jacques Russell, Edmond Tofux, Luna Petit-Renard and Johnny Chanteclair (deceased September 2020) for their help during the course of this study. We are grateful to J.P. Liégeois and to an anonymous reviewer who improved the manuscript by their judicious comments.

\section{Appendix A. Supplementary data}

\section{References}

Abdallah, N., Liégeois, J.P., De Waele, B., Fezaa, N., Ouabadi, A., 2007. The Temaguessine Fe-cordierite orbicular granite (Central Hoggar, Algeria): U-Pb SHRIMP age, petrology, origin and geodynamical consequences for the late Pan-African magmatism in the Tuareg Shield. J. Afr. Earth Sci. 49, 153-178.

Abdelsalam, M.G., Liégeois, J.P., Stern, R.J., 2002. The Saharan meta-craton. J. Afr. Earth Sc. 34, 153-178.

Arab, A., 2016. Les séries métasédimentaires de haute pression et les migmatites du socle de l'Egéré (Nord Hoggar): Télédétection, Géochimie et relations de phases $\mathrm{PhD}$. USTHB Alger.

Arab, A., Ouzegane, K., Drareni, A., Doukkari, S., Zetoutou, S., Kienast, J.R., 2015. Phase equilibria modeling of kyanite-bearing eclogitic metapelite in the NCKFMASHTO system from the Egéré terrane (Central Hoggar, South Algeria). Arab. J. Geosci.. doi:10.1007/s12517-014-1413-z.

Auzanneau, E., Vielzeuf, D., Schmidt, M.W., 2006. Experimental evidence of decompression melting during exhumation of subducted continental crust. Contrib. Miner. Petrol. 152, 125-148.

Auzanneau, E., Schmidt, M.W., Vielzeuf, D., Connelly, J.A.D., 2010. Titanium in phengite: a geobarometer for high temperature eclogites. Contrib. Miner. Petrol. 159, 1-24.
Barbey, P., Bertrand, J.M., Angoua, S., Dautel, D., 1989. Petrology and U/Pb geochronology of the Telohat migmatites, Aleksod, Central Hoggar, Algeria. Contrib. Mineral. Petrol. 101, 207-219.

Barth, A.P., Wooden, J.L., 2010. Coupled elemental and isotopic analyses of polygenetic zircons from granitic rocks by ion microprobe, with implications for melt evolution and the sources of granitic magmas. Chem. Geol. 277, 149-159.

Barth, A.P., Wooden, J.L., Mueller, P.A., Economos, R.C., 2016. Granite provenance and intrusion in arcs: evidence from diverse zircon types in Big Bear Intrusive Lake Suite, USA. Lithos 246-247, 261-278.

Bechiri-Benmerzoug, F., Liégeois, J.P., Bonin, B., Azzouni-Sekkal, A., Bechiri, H., Kheloui, R., Matukov, D.I., Sergeev, S.A., 2011. The plutons from the Cryogenian Iskel composite oceanic island arc (Hoggar, Tuareg Shield, Algeria): U-Pb on zircon SHRIMP geochronology, geochemistry and geodynamical setting. In: 7th Hutton Symposium on granites and related rocks, Avila, Spain, 4-9 July 2011. p. 17.

Bendaoud, A., Ouzegane, K., Godard, G., Liégeois, J.P., Kienast, J.R., Bruguier, O., Drareni, A., 2008. Geochronology and metamorphic P-T-X evolution of the Eburnean granulite facies metapelites of Tidjenouine (Central Hoggar, Algeria): witness of the LATEA metacratonic evolution. In: Ennih, N., Liégeois, J.P. (Eds.), The Boundaries of the West African Craton, Geol. Soc. London, Spec. Pub.. pp. 111-146.

Berger, J., Caby, R., Liégeois, J.P., Mercier, J.C., Demaiffe, D., 2011. Deep inside a neoproterozoic intra-oceanic arc: growth, differentiation and exhumation of the Amalaoulaou complex (Gourma, Mali). Contrib. Miner. Petrol. 162, 773-796.

Berger, J., Ouzegane, K., Bendaoud, A., Liégeois, J.P., Kiénast, J.R., Bruguier, O., Caby, R., 2014. Continental subduction recorded by Neoproterozoic eclogite and garnet amphibolite from Western Hoggar (Tassendjanet terrane, Tuareg Shield, Algeria). Precambr. Res. 247, 139-158.

Bertrand, J.M., 1974. Evolution polycyclique des gneiss précambriens de l'Aleksod (Hoggar Central, Sahara algérien). Aspects structuraux, pétrologiques, géochimiques et géochronologiques $\mathrm{PhD}$ thesis. Univ, Montpellier, p. 307.

Bertrand, J.M., Michard, A., Boullier, A.M., Dautel, D., 1986. Structure and U/Pb geochronology of Central Hoggar (Algeria): a reappraisal of its Pan-African evolution. Tectonics 5, 955-972.

Black, R., Latouche, L., Liégeois, J.P., Caby, R., Bertrand, J.M., 1994. Pan African displaced terranes in the Tuareg Shield (Central Sahara). Geology 22, 641-644.

Black, L.P., Williams, I.S., Compston, W., 1986. Four zircon ages from one rock: the history of a 3939 Ma old granulite from Mount Sones, Enderby Land, Antarctica. Contrib. Mineral. Petrol. 94, 427-437.

Black, L.P., Kamo, S.L., Allen, C.M., Davis, D.W., Aleinikoff, J.N., Valley, J.W., Mundil, R. Campbell, I.H., Korsch, R.J., Williams, I.S., Foudoulis, C., 2004. Improved ${ }^{206} \mathrm{~Pb} /{ }^{238} \mathrm{U}$ microprobe geochronology by the monitoring of a trace element-related matrix effect; SHRIMP, ID-TIMS, ELA-ICP-MS and oxygen isotope documentation for a series of zircon standard. Chem. Geol. 205, 115-140.

Bosch, D., Garrido, C.J., Bruguier, O., Dhuime, B., Bodinier, J.L., Padron-Navarta, J.A., Galland, B., 2011. Building an island arc crustal section: time constraints from a LA-ICP-MS zircon study. Earth Planet. Sci. Lett. 309, 268-279.

Blichert-Toft, J., Albarède, F., 1997. The Lu-Hf isotope geochemistry of chondrites and the evolution of the mantle-crust system. Earth Planet. Sci. Lett. 148, 243-258.

Bosch, D., Bruguier, O., Caby, R., Buscail, F., Hammor, D., 2016. Orogenic development of the Adrar des Iforas (Tuareg Shield, NE Mali): new geochemical and geochronological data and geodynamic implications. J. Geodyn. 96, 104-130.

Breeding, C.M., Ague, J.J., Grove, M., Rupke, A., 2004. Isotopic and chemical alteration of zircon by metamorphic fluids: U-Pb age depth-profiling of zircon crystals from Barrow's garnet zone, northeast Scotland. Am. Mineral 89, 1067-1077.

Bukala, M., Klonowska, I., Barnes, C., Majka, J., Kominska, K., Janak, M., Fassmer, K., Broman, C., Luptakova, J., 2018. UHP metamorphism recorded by phengite eclogite from the Caledonides of northern Sweden: P-T path and tectonic implications. J. Metamorph. Geol. 36, 547-566.

Caby, R., 2003. Terrane assembly and geodynamic evolution of Central-western Hoggar: a synthesis. J. Afr. Earth Sci. 37, 133-159.

Caby, R., Monié, P., 2003. Neoproterozoic subductions and differential exhumation of Western Hoggar (southwest Algeria): new structural, petrological and geochronological evidence. J. Afr. Earth Sc. 37, 269-293.

Caby, R., Bruguier, O., 2018. A subducted Neoproterozoic rift assemblage: the Egéré Group (Central Hoggar, Algeria). J. Afr. Earth Sci. 147, 544-553.

Caby, R., Andreopoulos-Renaud, U., Gravelle, M., 1982. Cadre géologique et géochronologique $\mathrm{U} / \mathrm{Pb}$ sur zircon des batholites précoces dans le segment Pan-Africain du Hoggar central (Algérie). Bull. Soc. Géol. Fr. 24, 677-684.

Chamberlain, C.P., Conrad, M.E., 1991. Oxygen isotope zoning in garnet. Science 254, 403-406.

Compston, W., Pidgeon, R.T., 1986. Jack Hills evidence of more very old detrital zircons in Western Australia. Nature 321, 766-769.

Cottle, J.M., Horstwood, M.S.A., Parrish, R.R., 2009. A new approach to single shot laser ablation analysis and its application to in situ $\mathrm{Pb} / \mathrm{U}$ geochronology. J. Anal. Atom. Spectr. 24, 1355-1363.

Doukkari, S.A., Ouzegane, K., Arab, A., Kienast, J.R., Godard, G., Drareni, A., Zetoutou, S., Liegeois, J.P., 2014. Phase relationships and P-T path in NCFMASHTO system of the eclogite from the Tighsi area (Egéré terrane, Central Hoggar, Algeria). J. Afr. Earth Sci. 99, 276-286.

Doukkari, S.A., Ouzegane, K., Godard, G., Diener, J., Kienast, J.R., Liegeois, J.P., Arab, A., Drareni, A., 2015. Prograde and retrograde evolution of eclogite from Adrar Izzilatène (Egéré-Aleksod terrane, Hoggar, Algeria) determined from chemical zoning and pseudosections, with geodynamic implications. Lithos 226, 217-232. 
El Hadi, H., Simancas, J., Martinez-Poyatos, D., Azor, A., Tahiri, A., Montero, P., Fanning, C., Bea, F., Gonzalez-Lodeiro, F., 2010. Structural and geochronological constraints on the evolution of the Bou Azzer Neoproterozoic ophiolite (Anti-Atlas, Morocco). Precambr. Res. 182, 1-14.

Ernst, W.G., 2001. Subduction, ultrahigh-pressure metamorphism, and regurgitation of buoyant crustal slices - implications for arc and continental growth. Phys. Earth Planet. Int. 127, 253-275.

Ferry, J.M., Watson, E.B., 2007. New thermodynamic models and revised calibrations for the Ti-in-zircon and Zr-in-rutile thermometers. Contrib. Miner. Petrol. 154, 429-437.

Fezaa, N., Liégeois, J.P., Abdallah, N., Cherfouh, E.H., De Waele, B., Bruguier, O., Ouabadi, A., 2010. Late Ediacarian geological evolution (575-555 Ma) of the Djanet terrane, Eastern Hoggar, Algeria: evidence for a Murzukian intracontinental episode. Precambr. Res. 180, 299-327.

Fisher, C.M., Hanchar, J.M., Samson, S.D., Dhuime, B., Blichert-Toft, J., Vervoort, J.D., Lam, R., 2011. Synthetic zircon doped with hafnium and rare earth elements: a reference material for in situ hafnium isotope analysis. Chem. Geol. 286, 32-47.

Fisher, C.M., Bauer, A.M., Luo, Y., Sarkar, C., Hanchar, J.M., Vervoort, J.D., Tapster, S.R., Horstwood, M., Pearson, D.G., 2020. Laser ablation split-stream analysis of the Sm-Nd and $\mathrm{U}-\mathrm{Pb}$ isotope compositions of monazite, titanite and apatite - Improvements, potential reference materials, and application to the Archean Saglek Block gneisses. Chem. Geol. 539.

Froude, D., Ireland, T., Kinny, P., Williams, I.S., Compston, W., Williams, I.R., Myers, J.S., 1983. Ion microprobe identification of 4,100-4,200 Myr-old terrestrial zircons. Nature 304, 616-618.

Ganade de Araujo, C.E., Rubatto, D., Hermann, J., Cordani, U.G., Caby, R., Basei, M.A., 2014. Ediacaran $2500 \mathrm{~km}$ long synchronous deep continental subduction in the West Gondwana Orogen. Nature. doi:10.1038/ncomms6198.

Gao, X.Y., Zheng, Y.F., Chen, Y.X., 2011. U-Pb ages and trace elements in metamorphic zircon and titanite from UHP eclogite in the Dabie orogen: constraints on P-T-t path. J. Metamorph. Geol. 29, 721-740.

Gao, Y.Y., Li, X.H., Griffin, W.L., O'Reilly, S.Y., Wang, Y.F., 2014. Screening criteria for reliable U-Pb geochronology and oxygen isotope analysis in uranium-rich zircons: a case study from the Suzhou A-type granites, SE China. Lithos 192-195, 180-191.

Gao, X.Y., Zheng, Y.F., Xia, X.P., Chen, Y.X., 2014. U-Pb ages and trace elements of metamorphic rutile from ultrahigh-pressure quartzite in the Sulu orogen. Geochim. Cosmochim. Acta 143, 87-114.

Gilotti, G.A., McClelland, W.C., Wooden, J.L., 2014. Zircon captures exhumation of an ultrahigh-pressure terrane, North-East Greenland Caledonides. Gondwana Res. 14, 235-256.

Günther, D., Heinrich, C.A., 1999. Enhanced sensitivity in LA-ICP-MS using helium-argon mixtures as aerosol carrier. J. Anal. Atom. Spectr. 14, 1369-1374.

Hawkesworth, C.J., Kemp, A.I.S., 2006. Using hafnium and oxygen isotopes in zircons to unravel the record of crustal evolution. Chem. Geol. 226, 144-162.

Hermann, J., Rubatto, D., 2009. Accessory phase control on the trace element signature of sediment melts in subduction zones. Chem. Geol. 265, 512-526.

Hoskin, P.W.O., Schaltegger, U., 2003. The composition of igneous zircon. In: Hanchar, J.M., Hoskin, P.W.O. (Eds.), Zircon. Rev. Mineral. Geochem.. pp. 27-62.

Jackson, S.E., Pearson, N.J., Griffin, W.L., Belousova, E.A., 2004. The application of laser ablation-inductively coupled plasma-mass spectrometry to in situ U-Pb zircon geochronology. Chem. Geol. 211, 47-69.

Jahn, B.M., Caby, R., Monié, P., 2001. The oldest UHP eclogites of the world: age of UHP metamorphism, nature of protoliths and tectonic implications. Chem. Geol. 178, 143-158.

Kemp, A.I.S., Foster, G.L., Scherstén, A., Whitehouse, M.J., Darling, J., Storey, C., 2009. Concurrent $\mathrm{Pb}-\mathrm{Hf}$ isotope analysis of zircon by laser ablation multi-collector ICP-MS, with implications for the crustal evolution of Greenland and the Himalayas. Chem. Geol. 261, 244-260.

Lancelot, J.R., Vitrac, A., Allègre, C.J., 1976. Uranium and lead isotopic dating with grain by grainzircon analysis: a study of complex geological history with a single rock. Earth Planet. Sci. Lett. 29, 357-366.

Liégeois, J.P., 2019. A new synthetic geological map of the Tuareg Shield: an overview of its global structure and geological evolution. In: Bendaoud, A., Hamimi, Z., Hamoudi, M., Djemai, S., Zoheir, B. (Eds.), The Geology of the Arab World - an overview. Springer, pp. 83-107.

Liégeois, J.P., Latouche, L., Boughrara, M., Navez, J., Guiraud, M., 2003. The LATEA metacraton (Central Hoggar, Tuareg Shield, Algeria): behavior of an old passive margin during the Pan-African orogeny. J. Afr. Earth Sci. 37, 161-190.

Liégeois, J.P., Abdelsalam, M.G., Ennih, N., Ouabadi, A., 2013. Metacraton: nature, genesis and behavior. Gondwana Res. 23, 220-237.

Ludwig, K.R., 2003. Isoplot/Ex. Spec. Pub.. Berkeley Geochronology Center, Berkeley California.

Martin, L., Duchêne, S., Deloule, E., Vanderhaeghe, O., 2006. The isotopic composition of zircon and garnet: a revord of the metamorphic history of Naxos, Greece. Lithos 87, 174-192.

Martin, L., Duchêne, S., Deloule, E., Vanderhaeghe, O., 2008. Mobility of trace elements and oxygen in zircon during metamorphism: consequences for geochemical tracing. Earth Planet. Sci. Lett. 267, 161-174.

McDonough, W.F., Sun, S.S., 1995. The composition of the Earth. Chem. Geol. 120, 223-253.

Meldrum, A., Boatner, L.A., Weber, W.J., Ewing, R.C., 1998. Radiation damage in zircon and monazite. Geochim. Cosmochim. Acta 62, 2509-2520.

Meyer, M., John, T., Brandt, S., Klemd, R., 2011. Trace element composition of rutile and the application of Zr-in-rutile thermometry to UHT metamorphism (Epupa Complex, NW Namibia). Lithos 126, 388-401.
Nahodilova, R., Stipska, P., Powell, R., Kosler, J., Racek, M., 2014. High-Ti muscovite as a prograde relict in high-pressure granulites with metamorphic Devonian zircon ages (Bestvina granulite body, Bohemian Massif): Consequences for the relamination model of subducted crust. Gondwana Res. 25, 630-648.

Page, F.Z., Cameron, E.M., Flood, C.M., Dobbins, J.W., Spicuzza, M.J., Kitajima, K., Strickland, A., Ushikubo, T., Mattinson, C.G., Valley, J.W., 2019. Extreme oxygen isotope zoning in garnet and zircon from a metachert block in mélange reveals metasomatism at the peak of subduction metamorphism. Geology 47, 655-658.

Patchett, J.P., Kouvo, O., Hedge, C.E., Tatsumoto, M., 1981. Evolution of continental crust and mantle heterogeneity: evidence from Hf isotopes. Contrib. Miner. Petrol. 78, 279-297.

Pearce, N.J.G., Perkins, W.T., Westgate, J.A., Gorton, M.P., Jackson, S.E., Neal, C.R., Chenery, S.P., 1997. A compilation of new and published major and trace data from NIST SRM 610 and NIST SRM 612 glass reference materials. Geostandards Newsl. 20, 247-261.

Peck, W.H, Valley, J.W., Graham, C.M., 2003. Slow oxygen diffusion rates in igneous zircons from metamorphic rocks. Am. Mineral. 88, 1003-1014.

Peucat, J.J., Drareni, A., Latouche, L., Deloule, E., Vidal, P., 2003. U-Pb zircon (TIMS and SIMS) and Sm-Nd whole rock geochronology of the Gour Oumelalen granulitic basement, Hoggar massif, Tuareg Shield, Algeria. J. Afr. Earth Sci. 37, 229-239.

Pidgeon, R.T., 1992. Recrystallisation of oscillatory zoned zircon - some geochronological and petrological implications. Contrib. Miner. Petrol. 110, 463-472.

Pidgeon, R.T., Nemchin, A.A., Whitehouse, M.J., 2017. The effect of weathering on $\mathrm{U}-\mathrm{Th}-\mathrm{Pb}$ and oxygen isotope systems of ancient zircons from the Jack Hills, Western Australia. Geochim. Cosmochim. Acta 197, 142-166.

Rey, P., Teyssier, C., Kruckenberg, S.C., Whitney, D., 2011. Viscous collision in channel explains double domes in metamorphic core complexes. Geology 39, 387-390.

Rubatto, D., 2002. Zircon trace element geochemistry: partitioning with garnet and the link between $\mathrm{U}-\mathrm{Pb}$ ages and metamorphism. Chem. Geol. 184, 123-138.

Rubatto, D., Hermann, J., Berger, A., Engi, M., 2009. Protracted fluid-induced melting during Barrovian metamorphism in the Central Alps. Contrib. Miner. Petrol. 158, 703-722.

Sautter, V., 1986. Les éclogites de l'Aleksod (Sud Algérien): des témoins in situ d'une collision continentale. J. Afr. Earth Sci. 5, 345-357.

Segal, I., Halicz, L., Platzner, I.T., 2003. Accurate isotope ratio measurements of ytterbium by multiple collection inductively coupled plasma mass spectrometry applying erbium and hafnium in an improved double external normalization procedure. J. Anal. Atom. Spectr. 18, 1217-1223.

Sengun, F., Zack, T., 2016. Trace element composition of rutile and Zr-in-rutile thermometry in meta-ophiolitic rocks from the Kazdag Massif, NW Turkey. Miner. Petrol. 110, 547-560.

Soderlund, U., Patchett, P.J., Vervoort, J.D., Isachsen, C.E., 2004. The ${ }^{176} \mathrm{Lu}$ decay constant determined by Lu-Hf and U-Pb isotope systematics of Precambrian mafic intrusions. Earth Planet. Sci. Lett. 219, 311-324.

Triebold, S., von Eynatten, H., Zack, T., 2012. A recipe for the use of rutile in sedimentary provenance analysis. Sedim. Geol. 282, 268-275.

van Achterberg, E., Ryan, C.G., Jackson, S.E., Griffin, W.L., 2001. Data reduction software for LA-ICP-MS: appendix. In: Sylvester, P.J. (Ed.), Laser ablation-ICP- Mass Spectrometry in the Earth Sciences: Principles and Applications. Mineralogical Association of Canada, Short Course Series, Ottawa, Ontario, Canada. pp. 239-243.

Vervoort, J.D., Patchett, P.J., Soderlund, U., Baker, M., 2004. Isotopic composition of $\mathrm{Yb}$ and the determination of $\mathrm{Lu}$ concentrations and $\mathrm{Lu} / \mathrm{Hf}$ by isotope dilution using MC-ICPMS. Geochem. Geophys. Geosys. 5, 1-15.

Vielzeuf, D., Holloway, J.R., 1988. Experimental determination of the fluid-absent melting relations in the pelitic system. Contrib. Miner. Petrol. 98, 257-276.

Watson, E.B., Cherniak, D.J., 1997. Oxygen diffusion in zircon. Earth Planet. Sci. Lett. 148, 527-544.

Wiedenbeck, M., Allé, P., Corfu, F., Griffin, W.L., Meier, M., 1995. Three natural zircon standards for U-Th-Pb, Lu-Hf, trace element and REE analyses. Geostandards Newsl. 19, 1-23.

Wiedenbeck, M, Hanchar, J.M., Peck, W.H., Sylvester, P., Valley, J., Whitehouse, M., Kronz, A., Morishita, Y., Nasdala, L., et al., 2004. Further characterisation of the 91500 zircon crystal. Geostandards Geoanal. Res. 28, 9-39.

Williams, I.S., Claesson, S., 1987. Isotopic evidence for the Precambrian provenance and Caledonian metamorphism of high grade paragneisses from the Seve Nappes, Scandinavian Caledonides. Part II. Ion microprobe zircon U-Th-Pb. Contrib. Miner. Petrol. 97, 205-217.

Yakymchuk, C., Kirkland, C.L., Clark, C., 2018. Th/U ratios in metamorphic zircon. J. Metamorph. Geol. 36, 715-737. doi:10.1111/jmg.12307.

Zetoutou, S., Ouzegane, K., Boubazine, S., Kienast, J.R, 2004. Azrou N'Fad (Central Hoggar, Algeria) one of the deepest terranes of LATEA: arguments based on P-T evolution in eclogite. J. Afr. Earth Sci. 39, 193-200.

Zheng, Y.F., Gao, X.Y., Chen, R.X., Gao, T.S., 2011. Zr-in-rutile thermometry of eclogite in the Dabie orogen: constraints on rutile growth during continental subduction-zone metamorphism. J. Asian Earth Sci. 40, 427-451.

Zong, K., Liu, Y., Gao, C., Hu, Z., Gao, S., Gong, H., 2010. In situ U-Pb dating and trace element analysis of zircons in thin sections of eclogite: Refining constraints on the ultra high-pressure metamorphism of the Sulu terrane, China. Chem. Geol. 269, 237-251. 